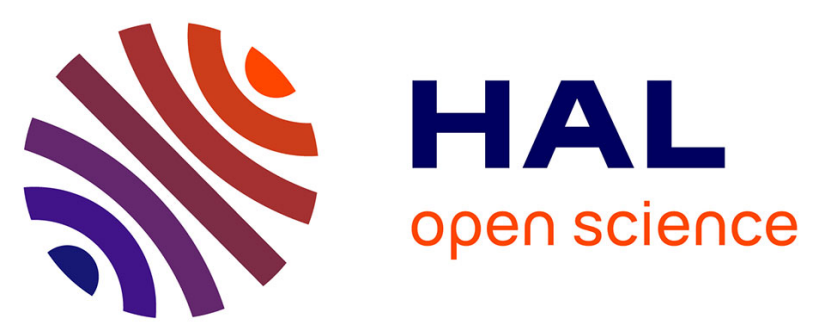

\title{
Developmental profiles of childhood attention-deficit/hyperactivity disorder and irritability: association with adolescent mental health, functional impairment, and suicidal outcomes
}

Cédric Galéra, Massimiliano Orri, Francis Vergunst, Maria Melchior, Judith van Der Waerden, Manuel Bouvard, Ophélie Collet, Michel Boivin, Richard E Tremblay, Sylvana M. Côté

\section{- To cite this version:}

Cédric Galéra, Massimiliano Orri, Francis Vergunst, Maria Melchior, Judith van Der Waerden, et al.. Developmental profiles of childhood attention-deficit/hyperactivity disorder and irritability: association with adolescent mental health, functional impairment, and suicidal outcomes. Journal of Child Psychology and Psychiatry, In press, 10.1111/jcpp.13270 . hal-02888482

\section{HAL Id: hal-02888482 https://hal.sorbonne-universite.fr/hal-02888482}

Submitted on 7 Jul 2020

HAL is a multi-disciplinary open access archive for the deposit and dissemination of scientific research documents, whether they are published or not. The documents may come from teaching and research institutions in France or abroad, or from public or private research centers.
L'archive ouverte pluridisciplinaire HAL, est destinée au dépôt et à la diffusion de documents scientifiques de niveau recherche, publiés ou non, émanant des établissements d'enseignement et de recherche français ou étrangers, des laboratoires publics ou privés. 


\title{
Developmental Profiles of Childhood Attention Deficit/Hyperactivity Disorder (ADHD) and
} Irritability: Association with Adolescent Mental Health, Functional Impairment and Suicidal Outcomes

Authors' names: Cedric Galera ${ }^{1,2,3,4}, \mathrm{MD}, \mathrm{PhD}$; Massimiliano Orri ${ }^{1,2,4,5}$, PhD; Francis Vergunst ${ }^{4}$, DPhil; Maria Melchior ${ }^{6,7}$, PhD; Judith Van der Waerden ${ }^{6,7}$, PhD; Manuel P. Bouvard ${ }^{2,3}$, Ophélie Collet $^{1,2}$, MSc; MD; Michel Boivin ${ }^{4,8,9}$, PhD; Richard E. Tremblay ${ }^{4,10,11,12,13}$, PhD; Sylvana M. Côté ${ }^{1,2,4,13}, \mathrm{PhD}$

\author{
Affiliations: \\ ${ }^{1}$ Bordeaux Population Health Research Center, INSERM U 1219, Bordeaux, France \\ ${ }^{2}$ Université de Bordeaux, Bordeaux, France \\ ${ }^{3}$ Department of Child and Adolescent Psychiatry, Centre Hospitalier Charles Perrens, Bordeaux, \\ France \\ ${ }^{4}$ Research Unit on Children's Psychosocial Maladjustment, Montreal, Quebec, Canada \\ ${ }^{5}$ McGill Group for Suicide Studies, Douglas Mental Health University Institute, Department of \\ Psychiatry, McGill University, Montreal, Quebec, Canada \\ ${ }^{6}$ Social Epidemiology Research Group, Institut Pierre Louis d'Epidémiologie et de Santé Publique \\ (IPLESP), INSERM UMR_S 1136, Paris \\ ${ }^{7}$ Sorbonne Universités, UPMC Univ Paris 06, Paris, France \\ ${ }^{8}$ School of Psychology, Université Laval, Quebec, Canada. \\ ${ }^{9}$ Institute of Genetic, Neurobiological, and Social Foundations of Child Development, Tomsk State \\ University, Tomsk, Russian Federation \\ ${ }^{10}$ School of Public Health, Physiotherapy and Sports Science, University College Dublin, Dublin, \\ Ireland \\ ${ }^{11}$ Department of Pediatrics, University of Montreal, Montreal, Quebec, Canada \\ ${ }^{12}$ Department of Psychology, University of Montreal, Montreal, Quebec, Canada \\ ${ }^{13}$ Department of Social and Preventive Medicine, University of Montreal, Montreal, Quebec, \\ Canada
}

Number of words: 5439

\section{Corresponding author:}

Cédric Galera. Bordeaux Population Health, INSERM U 1219, Team HEALTHY, University of Bordeaux, 146, rue Léo-Saignat, 33076 Bordeaux, France. cedric.galera@u-bordeaux.fr 


\section{ACKNOWLEDMENTS}

Dr Orri reports receiving a postdoctoral research fellowship from the Canadian Institutes of Health Research (CIHR). Dr Vergunst is funded by a Fonds de Recherche du Québec Santé (FRQS) postdoctoral fellowship. Drs Boivin and Tremblay report holding a Canada Research Chair in Child Development funded by the CIHR. Dr Côté reports being a research fellow of the Fonds de Recherche du Québec. Dr Tremblay reports being funded by the Canadian Institute of Advanced Research. All other authors declare no competing interests. Dr Bouvard has received financial support for the organization of and attendance at scientific meetings and was also the principal investigator in clinical trials for the pharmaceutical industry.

\section{CONTRIBUTORS}

CG contributed to the literature search, data analysis, data interpretation, and writing. MO contributed to the data analysis, data interpretation and writing. FV contributed to the data interpretation and writing. MM contributed to the data interpretation and writing. OC contributed to the data analysis, data interpretation, and writing. MPB contributed to the data interpretation and writing. JVW contributed to the data interpretation and writing. MPB contributed to the data interpretation and writing. MB contributed to the study design, data collection, data interpretation and writing. RET contributed to the study design, data collection, data interpretation and writing. SMC contributed to the study design, data collection, data analysis, data interpretation and writing. SMC had full access to all the data in the study and takes responsibility for the integrity of the data and the accuracy of the data analysis.

\section{FUNDING/SUPPORT}

The larger Québec Longitudinal Study of Child Development was supported by the Québec Government's Ministry of Health, Ministry of Education, and Ministry of Family Affairs, The Lucie and André Chagnon Foundation, the Robert-Sauvé Research Institute of Health and Safety at Work, and the Québec Statistics Institute. Additional funding was received from the Fonds de Recherche du Québec-Santé, the Fonds de Recherche du Québec-Societé et Culture, Canada's Social Science and Humanities Research Council, the Canadian Institutes of Health Research, and the St. Justine Research Center.

\section{ROLE OF THE FUNDER/SPONSOR}

Québec Statistics Institute collected data. The sponsors had no role in the design and conduct of the study; management, analysis, and interpretation of the data; preparation, review, or approval of the manuscript; and decision to submit the manuscript for publication. 


\section{KEY POINTS}

What's known: The high frequency of irritability in ADHD makes the combination of ADHD and irritability a phenotype particularly likely to be associated with greater severity in terms of psychiatric outcomes. However, there is a lack of large longitudinal studies from the general population describing the long-term covariations of ADHD and irritability during childhood and quantifying the associations with a wide range of psychiatric, functional impairment and suicidal outcomes during adolescence.

What's new: This study describes for the first time the developmental course of ADHD and irritability symptoms over 6 years, providing a graphical representation of the developmental heterogeneity. It shows that children with the combined ADHD/irritability phenotype are more likely to show externalizing, internalizing, functional impairment and suicidal outcomes during adolescence than children with moderately high ADHD or with moderately high irritability or low ADHD and irritability.

What's clinically relevant: Childhood irritability in ADHD is stable over time and the combined phenotype is a meaningful predictor of a broad array of clinical difficulties during adolescence. Clinicians should systematically track irritability when assessing ADHD and treat this dimension specifically with the aim of improving long-term outcomes. 


\begin{abstract}
Background: Irritability is frequently comorbid with ADHD. Although irritability alone has been linked to deleterious mental health and adaptive issues, the joint developmental course of ADHD and irritability symptoms during childhood as well as its association with later mental health and suicidal outcomes is not fully understood. We aimed to describe the developmental trajectories of childhood ADHD and irritability symptoms and to quantify their association with adolescent mental health and suicidal outcomes.
\end{abstract}

Methods: The Quebec Longitudinal Study of Child Development (QLSCD) included 1407 participants from the general population followed up from age 5 months to 17 years. We used a multi-trajectory approach to identify developmental trajectories of childhood (6-12 years) ADHD and irritability symptoms. Outcome measures were adolescent (13-17 years) mental health (psychiatric symptoms/functional impairment) and suicidal outcomes.

Results: We identified distinct developmental profiles: combined absent or very low ADHD and absent or very low irritability (940 [66.8\%]; reference group), moderately high irritability and low ADHD (158 [11.2\%]), moderately high ADHD and low irritability (198 [14.1\%]) and combined high ADHD and high irritability (111 [7.9\%]). Multivariate modeling showed that, compared to children in the reference group, those in the combined high ADHD and high irritability profile showed higher levels of ADHD continuity ( $\mathrm{d}$ ranges $=0.40-0.50)$, externalizing $(\mathrm{d}$ ranges $=0.25$ 0.59 ), internalizing ( $\mathrm{d}$ ranges $=0.20-0.29)$, and functional impairments ( $\mathrm{d}$ ranges $=0.17-0.48)$ and suicidal behaviors (Odds Ratio $(\mathrm{OR})=2.12$, Confidence Interval $(\mathrm{CI})=1.47-3.06)$ in adolescence. Conclusions: The presence of persistently high levels of irritability along with ADHD symptoms during childhood significantly predict adolescent ADHD continuity, externalizing, internalizing and suicidal outcomes. Systematic consideration of irritability when assessing and treating ADHD may improve long-term mental health outcomes.

Keywords: ADHD, Irritability, Mental health problems, Suicide, Functional impairment. 
Attention Deficit/Hyperactivity Disorder (ADHD) is a common and impairing behavioral condition defined by developmentally inadequate levels of inattention and hyperactivity-impulsivity. Whether or not emotional symptoms should be included in the core ADHD features has been largely debated. Although this option was not chosen in the latest nosographic classification (DSM-5), the relevance of the emotional dimension of ADHD remains the focus of active scientific/clinical research. 25 to $45 \%$ of youths with ADHD display disproportionately high levels of emotional symptoms (Shaw, Stringaris, Nigg, \& Leibenluft, 2014), which encompass a broad range of clinical features including emotional lability, impulsivity and dysregulation, and the concept of irritability (Faraone et al., 2019; Shaw et al., 2014; Vidal-Ribas, Brotman, Valdivieso, Leibenluft, \& Stringaris, 2016). From the clinician's perspective, irritability represents the most relevant emotional symptom to address. First, irritability is related to frequent requests for help due to the significant burden for the youth and the family. Second, it is clearly defined in the DSM-5 (American Psychiatric Association, 2013), which clarifies its clinical features and makes inter-rater reliability more accurate. Notably, irritability is characterized by frequent temper outbursts typically occurring in response to frustration and can be verbal or behavioral (i.e. aggression against property, self, or others). It is an observable behavior during interactions between children and their peers, teachers, and parents (Althoff, Verhulst, Rettew, Hudziak, \& van der Ende, 2010). Third, the combination of ADHD and irritability could mark a more severe entity, given its correlations with poorer outcomes and longterm impairments (Ambrosini, Bennett, \& Elia, 2013; Anastopoulos et al., 2011; Biederman et al., 2012; Eyre et al., 2017, 2019; Faraone et al., 2019; Lee et al., 2018; Seymour, Chronis-Tuscano, Iwamoto, Kurdziel, \& Macpherson, 2014; Surman et al., 2013; Wakschlag et al., 2015).

From the researcher's perspective, ADHD and irritability share neuropsychological, neural, genetic and environmental commonalities (Ambrosini et al., 2013). First, at a neuropsychological level, the association between irritability and ADHD may stem from a broad deficit in emotional selfregulation (Bunford, Evans, \& Langberg, 2018; Faraone et al., 2019; Shaw et al., 2014). Second, additional altered neuropsychological mechanisms described in ADHD (e.g. metacognition/executive functioning/motivation) (Faraone et al., 2019; Shaw et al., 2014), may be at play to jeopardize emotional regulation. Third, at the neural level, neuroimaging research suggests the involvement of cortical (i.e. orbitofrontal/prefrontal) and subcortical (i.e. 
amygdala/ventral striatum) structures/networks (Faraone et al., 2019; Pagliaccio et al., 2017; Shaw et al., 2014) in both ADHD and irritability. Finally, shared environmental (e.g. coercive parenting) and biological (e.g. genetic) risk factors may also explain the overlap between ADHD and irritability (Barkley, 2015; Shaw et al., 2014).

Prior research in this area has faced at least two kinds of limitation. First, the comorbid ADHD/irritability phenotype has often been poorly defined and constructed. Varying definitions of emotional symptoms and the lack of longitudinal appraisal hampered the ability to measure adequately covariations in ADHD and irritability symptoms as a function of time. Second, few studies have assessed the joint contribution of ADHD and irritability because they did not discriminate between individuals presenting with one or both dimensions. Thus, while the independent effect of ADHD and irritability has been examined, whether comorbid ADHD/irritability during the elementary school years predicts adolescent mental health, especially when compared to ADHD without irritability, has been insufficiently investigated. Yet understanding the developmental psychopathological sequences is key to clinical comprehension and to the effective implementation of screening/preventive measures (Brotman, Kircanski, \& Leibenluft, 2017; Shaw et al., 2014; Vidal-Ribas et al., 2016).

The aim of the present study was to overcome previous limitations by (1) identifying longitudinal profiles of ADHD and irritability symptoms during childhood, and (2) examining their associations with subsequent mental health problems, functional impairment, and suicidal behaviors during adolescence. We used a large birth cohort prospectively followed up for 17 years and applied multitrajectory modeling to capture the overlap between childhood ADHD and irritability.

\section{METHODS}

\section{Participants and procedure}

Data were drawn from the Quebec Longitudinal Study of Child Development (QLSCD), which was approved by the Quebec Statistics Institute and the St. Justine Hospital Research Center ethics committees. Participants were selected from the Quebec Birth Registry and stratified on birth rate/living area. Families were included if the pregnancy lasted 24-42 weeks and the mother could speak French or English. Data were collected by the Quebec Statistics Institute. Follow-up was conducted yearly during childhood and biyearly during adolescence. From 5 months to 13 years, trained interviewers collected data about parental, family, and child characteristics during home interviews conducted with the person most knowledgeable about the child (the mother in $98 \%$ of cases). Youths' behaviors were rated by teachers from 6 to 12 years and were self-reported from 13 to 17 years. Written informed consent was obtained from all the participants. The initial 
representative sample comprised 2120 infants born in the Canadian province of Quebec in 1997/1998. The information used to conduct the study relied on children's hyperactivityimpulsivity/inattention and irritability symptoms (6 to 12 years) and subsequent mental health problems (15 and 17 years), resulting in a sample of 1407 participants. The included and not included samples were similar except for child's sex and socioeconomic status (Table 1).

\section{Measures}

\section{Teacher Ratings of Childhood ADHD and Irritability Symptoms}

School teachers rated children on the Behavior Questionnaire at 6, 7, 8, 10, and 12 years. This questionnaire, created for the Canadian National Longitudinal Study of Children and Youth (Statistics Canada. Longitudinal Survey of Children and Youth (NLSCY)., 2009), includes items from the Child Behavior Checklist(Achenbach, Edelbrock, \& Howell, 1987), the Ontario Child Health Study Scales (Offord, Boyle, \& Racine, 1989), and the Preschool Behavior Questionnaire (Tremblay, R. E., s. d.). ADHD symptoms (i.e. hyperactivity-impulsivity and inattention) were evaluated using nine items ( $\alpha=.84-.88)$ : “could not sit still, was restless or hyperactive," "couldn't stop fidgeting," "was unable to wait when someone promised him/her something," "was impulsive, acted without thinking," "had difficulty waiting his/her turn in games," "couldn't settle down to do anything for more than a few moments," "was unable to concentrate, could not pay attention for long," "was easily distracted, had trouble sticking to any activity," "was inattentive". Items were rated using a 3-point Likert scale according to the frequency of the behavior during the past 6 months $(0=$ never $/ 1=$ sometimes $/ 2=$ often $)$. The child's behavior was assessed by a different teacher at each wave, thus reducing rater bias. At all points, the ADHD score was built by calculating the mean of the items. The score was standardized (range:0-10).

Teachers evaluated irritability symptoms using four items $(\alpha=.94-.97)$ (Orri et al., 2019; Orri, Galera, et al., 2018): "had temper tantrums or hot temper", "reacted in an aggressive manner when teased", "reacted in an aggressive manner when contradicted", "reacted in an aggressive manner when something was taken away from him/her". At all points, the irritability score was built by summing the first item (temper tantrum) with the mean of the other three items, as they assessed the same behavior (reacting in an aggressive manner) in three different situations. The score was standardized (range:0-10).

\section{Adolescents' Mental Health and Suicidal Outcomes}

Adolescents filled in the Mental Health and Social Inadaptation Assessment for Adolescents (MIA) which reflects the DSM-5 symptoms and shows good validity and reliability (Côté et al., 2017). 
The MIA included: 1) psychiatric symptoms (a) internalizing (social phobia/generalized anxiety/depression), b) externalizing (oppositional defiant disorder/conduct disorder/psychopathy/delinquency/contact with police/aggression), c) ADHD (hyperactivityimpulsivity/inattention)), d) eating disorders and 2) functional impairment (behavior/anxiety/depression/total). Mental health outcomes were assessed at ages 15 and 17 and the final scores were averaged across these two data points. Suicidal outcomes included suicidal ideation and suicide attempt assessed at ages 13, 15, and 17 years. Adolescents were asked, "In the past 12 months, did you ever seriously think of attempting suicide?" and if so, "How many times did you attempt suicide?". The variable lifetime suicidality (i.e. reporting $\geq 1$ serious suicide ideation or attempt at 13,15 , or 17 years) was derived.

\section{Data analysis}

\section{Estimating childhood ADHD and Irritability Profiles}

We estimated developmental trajectories of ADHD and irritability symptoms from 6 to 12 years using multi-trajectory modeling (Nagin, Jones, Passos, \& Tremblay, 2018). The multi-trajectory modeling method is a person-oriented approach that allows groups of individuals who share similar attributes to be identified. This application makes it possible to model the trajectories of multiple dimensions jointly using semi-parametric mixture models, and to identify different profiles defined by the joint development of symptoms across childhood. By identifying latent clusters of individuals following similar trajectories across multiple dimensions, multi-trajectory modeling allowed us to describe the overlap between ADHD and irritability symptoms. Parameters were estimated using maximum likelihood estimation by a Newton-Raphson optimization algorithm and censored-normal modeling. The selection of the best model in terms of number of groups and polynomial order of the trajectories was based on interpretability and statistics including several fit indices (log-likelihood/Bayesian information criterion/entropy/mean odds of correct classification). The assignment of each participant to a specific profile was based on the highest posterior probability.

\section{Quantifying the Associations between Childhood ADHD and Irritability Profiles and} Adolescent Mental Health and Suicidal Outcomes

In order to provide a broad picture regarding the possible mental health outcomes associated with the ADHD and irritability profiles, we conducted a series of regression models. We used linear regression models to estimate the associations of childhood ADHD and irritability profiles with adolescent mental health problems, the reference being the profile with the lowest level of 
symptoms, and $\beta$ representing the change in the mental health score (range:0-10) as a function of the profile. We used logistic regression models to estimate the associations between childhood profiles and suicidal outcomes (odds ratios (ORs) with their $95 \%$ confidence intervals (CI)). We conducted all the analyses using inverse probability weighting to handle sample attrition (based on key variables significantly associated with attrition). The objective of this analysis was to weight observations, taking into account the fact that individuals with certain characteristics are more likely to be missing at follow-up, thus compromising the generalizability of the results with respect to the initial cohort sample. We applied the Benjamini-Hochberg procedure (Benjamini, 2010) to correct for multiple testing. We computed Cohen's d as a measure of effect sizes. All the estimates were standardized. We systematically adjusted on child's sex, family socioeconomic status, maternal age at childbirth, no intact family, maternal and paternal hostile-reactive parenting score, maternal depression, maternal and paternal antisociality in adolescence. We tested sex $\times$ profile interactions. We conducted further secondary analyses: 1) stratifying by sex, independently from the significance of interaction, given the underpower of interaction testing in multivariate modeling and the large sex differences in mental health/suicidal outcomes (Schrijvers, Bollen, \& Sabbe, 2012; Zahn-Waxler, Klimes-Dougan, \& Slattery, 2000); 2) comparing profiles with one another to explore whether the distinct profiles differed. Finally, we conducted sensitivity analyses without inverse probability weights.

\section{RESULTS}

\section{Estimating Childhood ADHD and Irritability Profiles}

The study included 1407 children followed up to 17 years of age (742 (52.7\%) females and 665 (47.3\%) males). The model with five profiles was chosen because it represented the best compromise in terms of both statistics and interpretability, compared to the alternatives (eTable 1). This model is shown in Figure 1: (A) no ADHD and no irritability (401 [28.5\%]), (B) very low ADHD and very low irritability (539 [38.3\%]), (C) moderately high ADHD and low irritability (198 [14.1\%]), (D) moderately high irritability and low ADHD (158 [11.2\%]), and (E) combined high ADHD and high irritability (111 [7.9\%]). Fit indices of the model were good: log-likelihood=17,336.34; $\mathrm{BIC}=-17,424.77$; entropy $=0.79$ (adequate if $>0.70$ ); mean odds of correct classification=16.01 (adequate if $>5.0$ ). The combined profile displayed the highest levels of both ADHD and irritability symptoms. Profiles 1 and 2 were merged to build a reference group showing no/very low levels of both ADHD and irritability, thus likely to correspond to a clinically nonproblematic group (940 [66.8\%]). Individual and family characteristics of each profile are presented in Table 2. When compared to the reference group, children with high ADHD and high irritability 
were more likely to be male, to have low socioeconomic status, younger mothers, depressed mothers, maternal and paternal adolescent antisociality, to come from non-intact families, and to be exposed to hostile-reactive parenting (all $\mathrm{p}<0.01$ ). The distribution of adolescent mental health problems and suicidal outcomes by childhood profile of ADHD and irritability by sex is presented in eTable 2.

\section{Quantifying the Associations between Childhood ADHD and Irritability Profiles and}

\section{Adolescent Mental Health and Suicidal Outcomes}

Table 3 reports the weighted associations between childhood profiles, adolescent psychiatric symptoms, suicidal outcomes, and adolescent functional impairment in the whole sample. The combined high ADHD and high irritability profile was consistently associated with higher risk levels of adolescent psychiatric symptoms (i.e. internalizing, ADHD, externalizing), suicidal outcomes, and functional impairments due to behavior, anxiety, depression, and total score symptoms compared to the reference group. Effect sizes ranges were: $\mathrm{d}=0.20-0.29$ for internalizing symptoms, $d=0.40-0.50$ for ADHD symptoms, $d=0.25-0.59$ for externalizing symptoms, $d=0.17$ 0.48 for functional impairment. The increase in the odds of suicidal outcomes was more than twofold higher (when compared to the reference group). The moderately high ADHD and low irritability profile was weakly associated with adolescent ADHD symptoms $(\mathrm{d}=0.10-0.32)$ externalizing symptoms $(\mathrm{d}=0.06-0.23)$, suicidal outcomes $(\mathrm{OR}=1.50)$, and functional impairment $(\mathrm{d}=0.02-0.20)$. The moderately high irritability and low ADHD profile was weakly associated with the outcomes in terms of effect sizes and number of outcomes. It was associated with adolescent ADHD symptoms $(\mathrm{d}=0.14-0.22)$, externalizing symptoms $(\mathrm{d}=-0.03-0.24)$, and functional impairment $(\mathrm{d}=0.11-0.25)$.

eTable 3 displays the weighted associations between childhood profiles, adolescent psychiatric symptoms, suicidal outcomes, and adolescent functional impairment stratified by sex. The combined high ADHD and high irritability profile was consistently associated with higher risk levels of adolescent psychiatric symptoms, suicidal outcomes, and functional impairments due to anxiety, depression, and total score symptoms compared to the reference group, both in females and in males. In females, effect sizes were large for delinquency and contact with police, and aggression. The moderately high ADHD and low irritability profile was weakly associated with adolescent ADHD symptoms (in males and females), externalizing symptoms (in males), and suicidal outcomes (in males). The moderately high irritability and low ADHD profile was associated with adolescent ADHD symptoms (in males), externalizing symptoms (in females), and suicidality (in males) and total functional impairment (in females). In females, it was also associated 
with functional impairment due to behavior, anxiety, depression.

eTable 4 shows the associations between childhood profiles and adolescent outcomes using different reference categories. The combined high ADHD and high irritability profile was significantly associated with more severe psychiatric (internalizing, externalizing and ADHD) symptoms and functional impairment, when compared to the two other groups (i.e. moderately high ADHD and low irritability/moderately high irritability and low ADHD). We found significant sex $\times$ profile interactions regarding social phobia, suicidality and the functional impairment scale for depression. Results were robust to attrition in unweighted sensitivity analyses (eTable 5).

\section{DISCUSSION}

To our knowledge, this is the first investigation of the developmental pattern of ADHD and irritability over a period of 6 years during childhood and its associations with mental health, functional impairment and suicidal outcomes during adolescence. We identified different clusters of symptom evolution (i.e. combined high ADHD/irritability, moderately high ADHD and low irritability, moderately high irritability and low ADHD, and two clusters of no/very low levels of ADHD/irritability) and showed that the children in the combined high ADHD/Irritability profile presented a significantly severe phenotype. First, children in the combined phenotype presented with a higher severity of concurrent ADHD symptoms compared to the level of ADHD symptoms of all groups including the moderately high ADHD and low irritability profile, consistently with the literature (Vidal-Ribas et al., 2016). Second, these children had a higher propensity than those in the other profiles to exhibit enduring ADHD symptoms later on, confirming prior findings (Biederman et al., 2012). Third, these children showed the worst adolescent outcomes including higher psychiatric symptoms (externalizing, and internalizing), higher functional impairments, and suicidal behaviors compared to the lowest level of ADHD and irritability. Underlying the clinical/predictive importance of the combined phenotype, effect sizes for psychiatric symptoms and impairment were often beyond the medium range, and the increase in the risk for suicidal behavior was more than twofold. Other developmental profiles were related to impaired outcomes, but to a lesser extent. Moderately high ADHD and low irritability in childhood was linked to externalizing symptoms and suicidal behaviors, and functional impairment, in adolescence. The fact that irritability may add internalizing problems to ADHD without irritability is consistent with evidence showing a specific increase in irritability in the liability towards depression and anxiety. Moderately high irritability and low ADHD was modestly related to psychiatric symptoms and functional impairment. Analyses by sex suggested stronger associations in females than in males, although their exploratory nature 
calls for cautious interpretation. In females, the combined high ADHD/Irritability phenotype had strong associations with aggression, delinquency and contact with police, thus identifying a small but high-risk subgroup regarding long-term adverse outcomes.

Neuropsychological and neural mechanisms as well as environmental/biological commonalities may underpin the association between ADHD and irritability. Particularly, the broad deficit in emotional self-regulation can lead to hampered response inhibition to evocative situations and translates into excessive/inadequate behaviors when frustrated (Barkley, 2015; Faraone et al., 2019; Shaw et al., 2014). This results in harmful consequences, especially by triggering hostile feelings in peers/caretakers, thus generating bidirectional negative relationships with the social environment. Pathways from comorbid ADHD/irritability to mental health problems could rest on short- and long-term environmental consequences. Impairments in adaptive, daily living and social skills, propensity to fight, rejection from peers and adults, academic failure, lowered quality of life and self-esteem (Anastopoulos et al., 2011; Bunford et al., 2018; Lee et al., 2018; Surman et al., 2013) are risk factors for psychiatric problems. Beyond internalizing/externalizing problems, emotional distress combined with the tendency to act impulsively makes individuals more prone to suicidal ideation and attempted suicide (Benarous et al., 2018; Orri, Perret, Turecki, \& Geoffroy, 2018). The multi-finality of environmental/biological commonalities may also underlie the associations between ADHD, irritability, internalizing and externalizing problems. Finally, whether the link between the combined phenotype and a more severe clinical evolution during adolescence is due to irritability in itself or to a more severe ADHD in childhood could not be disentangled by our study. Future investigations will be needed to better understand this point.

\section{Strengths and limitations}

The present study has several strengths. First, it used a large population-based sample followed from childhood to adolescence. Second, it was methodologically innovative by allowing the concurrent appraisal of irritability and ADHD symptoms over 6 years. However, the study has limitations. First, the study sample is likely to represent a less at-risk sample compared to the initial sample and the observed associations are potentially underestimated. Indeed, the study was subject to significant attrition. Despite the use of inverse probability weighting in the main analyses, this attrition may still have influenced the results, thus limiting the generalizability of the findings to the general population. Second, it must be acknowledged that irritability is close to the older concept of aggressive behavior. Although the two concepts are part of the same phenomenon, they do not strictly tap the same construct. As defined in the DSM5, irritability incorporates temper tantrums and reacting in an aggressive manner. On the other hand, aggressive behavior includes proactive and hostile aggression with the intention of inflicting harm or damage, and not only reactive 
aggression. Third, behavioral assessments relied on symptom-based scales rather than clinical tools. However, these instruments have shown satisfactory psychometric properties (Tremblay, R. E., s. d.), and the dimensional approach in a population-based sample may be more accurate when the aim of the research is to quantify associations between psychopathological risk factors and outcomes. Fourth, teachers assessed childhood behaviors. Changing raters' perspectives over time could generate a bias of instability. In addition, the lack of parental evaluation prevented the appraisal of behavior problems limited to the home setting (Stringaris, Vidal-Ribas, Brotman, \& Leibenluft, 2018). However, compared to parent reports or self-reports, teacher reports are sensitive to the environment in which the children live (i.e. school setting), because teachers interact daily over many years with numerous children of the same age. Thus, they are well placed to identify departures from normality, particularly regarding externalizing symptoms (Kerr, Lunkenheimer, \& Olson, 2007; Saudino, Ronald, \& Plomin, 2005). Fifth, parental reports were not available for childhood irritability or for adolescent mental health outcomes. Further studies should consider combinations of parental and teacher/youth reports. Sixth, the fact that adolescent data relied on self-reports could be viewed as problematic, especially in youths with ADHD, who might have a positive illusory bias in reporting their own functioning. Reassuringly, there is evidence that selfrated measures of both internalizing and externalizing problems are relevant as children become adolescents. Regarding externalizing symptoms, covert behaviors hidden from adults can be accurately evaluated through adolescent self-reports (Augenstein et al., 2016; Schaughency, McGee, Raja, Feehan, \& Silva, 1994; Ustun et al., 2017). Regarding internalizing problems, the improvement in introspection with age allows a better appraisal of emotions (Salbach-Andrae, Klinkowski, Lenz, \& Lehmkuhl, 2009; Swanson et al., 2014). Seventh, our study used a personoriented approach regarding ADHD/irritability. Future research should include a variable-oriented approach to complement the present findings.

\section{Implications}

Whether irritability should be considered a core symptom of ADHD, a distinct but correlated dimension or a distinct entity is not yet clear. Irritability is non-specific, since it is also encountered in people without ADHD. Reciprocally, emotional symptoms are not constant in ADHD. In addition, other constructs (e.g. emotional impulsivity, deficient emotional self-regulation) might better tap the dysregulated emotionality of ADHD (Faraone et al., 2019; Surman et al., 2013). The transnosographic nature of irritability raises the question of whether the combined ADHD/phenotype reflects the role of other diagnostic comorbidities (e.g. oppositional defiant disorder, disruptive mood dysregulation disorder, depressive disorders, and bipolar disorder 
(Faraone et al., 2019). Bipolar disorder is very rare during childhood and is unlikely to explain our results. In addition, a recent molecular study relying on polygenic risk scores showed that irritability was more likely associated with ADHD than with mood and anxiety disorders (Riglin et al., 2017). Our findings have clinical implications. First, they suggest that systematic assessment of irritability with specific tools should be undertaken when diagnosing/monitoring ADHD, due to the clinical cross-sectional and longitudinal relevance of irritability. Second, ADHD interventions should target irritability when present, although the most effective interventions remain to be determined. Interestingly, irritability in ADHD is partly improved by ADHD treatments. Psychological interventions, including cognitive-behavioral, metacognitive, mindfulness therapies and parent behavior management training have shown promising results (Waxmonsky et al., 2016). By helping youths to regulate stress and label emotions, and by supporting parents to interrupt negative family dynamics, these interventions may be clinically beneficial for comorbid children. Stimulant and non-stimulant medications are somewhat efficient in the short term to reduce emotional symptoms (Blader et al., 2016; Moukhtarian, Cooper, Vassos, Moran, \& Asherson, 2017). However, whether decreasing childhood irritability improves adolescent mental health and suicidal outcomes remains to be shown in randomized controlled trials.

\section{Conclusions}

The present study suggests that, at the extreme of the dysregulation spectrum, the combination of childhood ADHD and irritability is associated with a more severe clinical evolution during adolescence, including higher ADHD continuity and a wider spectrum of subsequent mental health problems, with additional internalizing outcomes compared to ADHD without irritability. If replicated in other population samples and settings, the findings suggest that better consideration of irritability when assessing and treating ADHD would allow a more accurate appraisal of the clinical heterogeneity of ADHD and would likely improve mental health and suicidal outcomes. Addressing the transnosographic dimension of irritability when assessing ADHD is necessary to enhance our etiologic understanding and to develop more efficient interventions. Future research on the irritable dimension of ADHD should target early risk factors, explore age differences and test interventions.

\section{REFERENCES}

Achenbach, T. M., Edelbrock, C., \& Howell, C. T. (1987). Empirically based assessment of the behavioral/emotional problems of 2- and 3- year-old children. Journal of Abnormal Child Psychology, 15(4), 629-650. 
Althoff, R. R., Verhulst, F. C., Rettew, D. C., Hudziak, J. J., \& van der Ende, J. (2010). Adult Outcomes of Childhood Dysregulation: A 14-year Follow-up Study. Journal of the American Academy of Child \& Adolescent Psychiatry, 49(11), 1105-1116.e1. https://doi.org/10.1016/j.jaac.2010.08.006

Ambrosini, P. J., Bennett, D. S., \& Elia, J. (2013). Attention deficit hyperactivity disorder characteristics: II. Clinical correlates of irritable mood. Journal of Affective Disorders, 145(1), 70-76. https://doi.org/10.1016/j.jad.2012.07.014

American Psychiatric Association. (2013). Diagnostic and statistical manual of mental disorders (5th éd.). Arlington: VA: American Psychiatric Publishing.

Anastopoulos, A. D., Smith, T. F., Garrett, M. E., Morrissey-Kane, E., Schatz, N. K., Sommer, J. L., ... Ashley-Koch, A. (2011). Self-Regulation of Emotion, Functional Impairment, and Comorbidity Among Children With AD/HD. Journal of Attention Disorders, 15(7), 583-592. https://doi.org/10.1177/1087054710370567

Augenstein, T. M., Thomas, S. A., Ehrlich, K. B., Daruwala, S., Reyes, S. M., Chrabaszcz, J. S., \& De Los Reyes, A. (2016). Comparing Multi-Informant Assessment Measures of Parental Monitoring and Their Links with Adolescent Delinquent Behavior. Parenting, 16(3), 164-186. https://doi.org/10.1080/15295192.2016.1158600

Barkley, R. A. (Éd.). (2015). Attention-deficit hyperactivity disorder: A handbook for diagnosis and treatment (4. ed). New York: The Guilford Press.

Benarous, X., Consoli, A., Cohen, D., Renaud, J., Lahaye, H., \& Guilé, J.-M. (2018). Suicidal behaviors and irritability in children and adolescents: A systematic review of the nature and mechanisms of the association. European Child \& Adolescent Psychiatry. https://doi.org/10.1007/s00787-018-1234-9

Benjamini, Y. (2010). Discovering the false discovery rate: False Discovery Rate. Journal of the Royal Statistical Society: Series B (Statistical Methodology), 72(4), 405-416. https://doi.org/10.1111/j.1467-9868.2010.00746.x

Biederman, J., Spencer, Petty, O’Connor, Hyder, Surman, \& Faraone. (2012). Longitudinal course of deficient emotional self-regulation CBCL profile in youth with ADHD: Prospective controlled study. Neuropsychiatric Disease and Treatment, 267. 
https://doi.org/10.2147/NDT.S29670

Blader, J. C., Pliszka, S. R., Kafantaris, V., Sauder, C., Posner, J., Foley, C. A., ... Margulies, D. M. (2016). Prevalence and Treatment Outcomes of Persistent Negative Mood Among Children with Attention-Deficit/Hyperactivity Disorder and Aggressive Behavior. Journal of Child and Adolescent Psychopharmacology, 26(2), 164-173.

https://doi.org/10.1089/cap.2015.0112

Brotman, M. A., Kircanski, K., \& Leibenluft, E. (2017). Irritability in Children and Adolescents. Annual Review of Clinical Psychology, 13, 317-341. https://doi.org/10.1146/annurevclinpsy-032816-044941

Bunford, N., Evans, S. W., \& Langberg, J. M. (2018). Emotion Dysregulation Is Associated with Social Impairment Among Young Adolescents With ADHD. Journal of Attention Disorders, 22(1), 66-82. https://doi.org/10.1177/1087054714527793

Côté, S. M., Orri, M., Brendgen, M., Vitaro, F., Boivin, M., Japel, C., ... Tremblay, R. E. (2017). Psychometric properties of the Mental Health and Social Inadaptation Assessment for Adolescents (MIA) in a population-based sample. International Journal of Methods in Psychiatric Research, 26(4). https://doi.org/10.1002/mpr.1566

Eyre, O., Langley, K., Stringaris, A., Leibenluft, E., Collishaw, S., \& Thapar, A. (2017). Irritability in ADHD: Associations with depression liability. Journal of Affective Disorders, 215, 281-287. https://doi.org/10.1016/j.jad.2017.03.050

Eyre, O., Riglin, L., Leibenluft, E., Stringaris, A., Collishaw, S., \& Thapar, A. (2019). Irritability in ADHD: Association with later depression symptoms. European Child \& Adolescent Psychiatry. https://doi.org/10.1007/s00787-019-01303-x

Faraone, S. V., Rostain, A. L., Blader, J., Busch, B., Childress, A. C., Connor, D. F., \& Newcorn, J. H. (2019). Practitioner Review: Emotional dysregulation in attention-deficit/hyperactivity disorder - implications for clinical recognition and intervention. Journal of Child Psychology and Psychiatry, and Allied Disciplines, 60(2), 133-150. https://doi.org/10.1111/jcpp.12899

Kerr, D. C. R., Lunkenheimer, E. S., \& Olson, S. L. (2007). Assessment of child problem behaviors by multiple informants: A longitudinal study from preschool to school entry. Journal of 
Child Psychology and Psychiatry, and Allied Disciplines, 48(10), 967-975. https://doi.org/10.1111/j.1469-7610.2007.01776.x

Lee, C. A., Milich, R., Lorch, E. P., Flory, K., Owens, J. S., Lamont, A. E., \& Evans, S. W. (2018). Forming first impressions of children: The role of attention-deficit/hyperactivity disorder symptoms and emotion dysregulation. Journal of Child Psychology and Psychiatry, 59(5), 556-564. https://doi.org/10.1111/jcpp.12835

Moukhtarian, T. R., Cooper, R. E., Vassos, E., Moran, P., \& Asherson, P. (2017). Effects of stimulants and atomoxetine on emotional lability in adults: A systematic review and metaanalysis. European Psychiatry, 44, 198-207. https://doi.org/10.1016/j.eurpsy.2017.05.021

Nagin, D. S., Jones, B. L., Passos, V. L., \& Tremblay, R. E. (2018). Group-based multi-trajectory modeling. Statistical Methods in Medical Research, 27(7), 2015-2023. https://doi.org/10.1177/0962280216673085

Offord, D. R., Boyle, M. H., \& Racine, Y. (1989). Ontario Child Health Study: Correlates of disorder. Journal of the American Academy of Child and Adolescent Psychiatry, 28(6), 856-860. https://doi.org/10.1097/00004583-198911000-00008

Orri, M., Galera, C., Turecki, G., Boivin, M., Tremblay, R. E., Geoffroy, M.-C., \& Côté, S. M. (2019). Pathways of Association Between Childhood Irritability and Adolescent Suicidality. Journal of the American Academy of Child and Adolescent Psychiatry, 58(1), 99-107.e3. https://doi.org/10.1016/j.jaac.2018.06.034

Orri, M., Galera, C., Turecki, G., Forte, A., Renaud, J., Boivin, M., ... Geoffroy, M.-C. (2018). Association of Childhood Irritability and Depressive/Anxious Mood Profiles with Adolescent Suicidal Ideation and Attempts. JAMA Psychiatry, 75(5), 465-473. https://doi.org/10.1001/jamapsychiatry.2018.0174

Orri, M., Perret, L. C., Turecki, G., \& Geoffroy, M.-C. (2018). Association between irritability and suicide-related outcomes across the life-course. Systematic review of both community and clinical studies. Journal of Affective Disorders, 239, 220-233. https://doi.org/10.1016/j.jad.2018.07.010

Pagliaccio, D., Wiggins, J. L., Adleman, N. E., Curhan, A., Zhang, S., Towbin, K. E., ... Leibenluft, E. (2017). Behavioral and Neural Sustained Attention Deficits in Disruptive 
Mood Dysregulation Disorder and Attention-Deficit/Hyperactivity Disorder. Journal of the American Academy of Child \& Adolescent Psychiatry, 56(5), 426-435. https://doi.org/10.1016/j.jaac.2017.02.008

Riglin, L., Eyre, O., Cooper, M., Collishaw, S., Martin, J., Langley, K., ... Thapar, A. (2017). Investigating the genetic underpinnings of early-life irritability. Translational Psychiatry, 7(9), e1241. https://doi.org/10.1038/tp.2017.212

Salbach-Andrae, H., Klinkowski, N., Lenz, K., \& Lehmkuhl, U. (2009). Agreement between youthreported and parent-reported psychopathology in a referred sample. European Child \& Adolescent Psychiatry, 18(3), 136-143. https://doi.org/10.1007/s00787-008-0710-z

Saudino, K. J., Ronald, A., \& Plomin, R. (2005). The etiology of behavior problems in 7-year-old twins: Substantial genetic influence and negligible shared environmental influence for parent ratings and ratings by same and different teachers. Journal of Abnormal Child Psychology, 33(1), 113-130.

Schaughency, E., McGee, R., Raja, S. N., Feehan, M., \& Silva, P. A. (1994). Self-reported inattention, impulsivity, and hyperactivity at ages 15 and 18 years in the general population. Journal of the American Academy of Child and Adolescent Psychiatry, 33(2), 173-184. https://doi.org/10.1097/00004583-199402000-00004

Schrijvers, D. L., Bollen, J., \& Sabbe, B. G. C. (2012). The gender paradox in suicidal behavior and its impact on the suicidal process. Journal of Affective Disorders, 138(1-2), 19-26. https://doi.org/10.1016/j.jad.2011.03.050

Seymour, K. E., Chronis-Tuscano, A., Iwamoto, D. K., Kurdziel, G., \& Macpherson, L. (2014). Emotion regulation mediates the association between ADHD and depressive symptoms in a community sample of youth. Journal of Abnormal Child Psychology, 42(4), 611-621. https://doi.org/10.1007/s10802-013-9799-8

Shaw, P., Stringaris, A., Nigg, J., \& Leibenluft, E. (2014). Emotion Dysregulation in Attention Deficit Hyperactivity Disorder. American Journal of Psychiatry, 171(3), 276-293. https://doi.org/10.1176/appi.ajp.2013.13070966

Statistics Canada. Longitudinal Survey of Children and Youth (NLSCY). (2009, mai 14). Consulté à l'adresse http://www23.statcan.gc.ca/imdb/p2SV.pl?Function=getSurvey\&SDDS=4450 
Stringaris, A., Vidal-Ribas, P., Brotman, M. A., \& Leibenluft, E. (2018). Practitioner Review: Definition, recognition, and treatment challenges of irritability in young people. Journal of Child Psychology and Psychiatry, and Allied Disciplines, 59(7), 721-739. https://doi.org/10.1111/jcpp.12823

Surman, C. B. H., Biederman, J., Spencer, T., Miller, C. A., McDermott, K. M., \& Faraone, S. V. (2013). Understanding deficient emotional self-regulation in adults with attention deficit hyperactivity disorder: A controlled study. ADHD Attention Deficit and Hyperactivity Disorders, 5(3), 273-281. https://doi.org/10.1007/s12402-012-0100-8

Swanson, S. A., Aloisio, K. M., Horton, N. J., Sonneville, K. R., Crosby, R. D., Eddy, K. T., ... Micali, N. (2014). Assessing eating disorder symptoms in adolescence: Is there a role for multiple informants? Parent and Adolescent Report of Eating Disorder Symptoms. International Journal of Eating Disorders, 47(5), 475-482. https://doi.org/10.1002/eat.22250

Tremblay, R. E. (s. d.). Lampeter, Wales: Edwin Mellen Press. In Commissioned reviews on 300 psychological tests (Lampeter, Wales: Edwin Mellen Press., p. 767-771). In J. Maltby, C. A. Lewis, \& A. P. Hill.

Ustun, B., Adler, L. A., Rudin, C., Faraone, S. V., Spencer, T. J., Berglund, P., ... Kessler, R. C. (2017). The World Health Organization Adult Attention-Deficit/Hyperactivity Disorder Self-Report Screening Scale for DSM-5. JAMA Psychiatry, 74(5), 520. https://doi.org/10.1001/jamapsychiatry.2017.0298

Vidal-Ribas, P., Brotman, M. A., Valdivieso, I., Leibenluft, E., \& Stringaris, A. (2016). The Status of Irritability in Psychiatry: A Conceptual and Quantitative Review. Journal of the American Academy of Child \& Adolescent Psychiatry, 55(7), 556-570. https://doi.org/10.1016/j.jaac.2016.04.014

Wakschlag, L. S., Estabrook, R., Petitclerc, A., Henry, D., Burns, J. L., Perlman, S. B., ... BriggsGowan, M. L. (2015). Clinical Implications of a Dimensional Approach: The Normal:Abnormal Spectrum of Early Irritability. Journal of the American Academy of Child \& Adolescent Psychiatry, 54(8), 626-634. https://doi.org/10.1016/j.jaac.2015.05.016 Waxmonsky, J. G., Waschbusch, D. A., Belin, P., Li, T., Babocsai, L., Humphery, H., ... Pelham, 
W. E. (2016). A Randomized Clinical Trial of an Integrative Group Therapy for Children with Severe Mood Dysregulation. Journal of the American Academy of Child and Adolescent Psychiatry, 55(3), 196-207. https://doi.org/10.1016/j.jaac.2015.12.011

Zahn-Waxler, C., Klimes-Dougan, B., \& Slattery, M. J. (2000). Internalizing problems of childhood and adolescence: Prospects, pitfalls, and progress in understanding the development of anxiety and depression. Development and Psychopathology, 12(3), 443-466. 
Table 1. Comparison of participants vs. non-participants on key variables ${ }^{a}, \mathrm{n}=2,120, \mathrm{ELDEQ}$, Canada, 1998-2015.

\begin{tabular}{|c|c|c|c|}
\hline Characteristics & $\begin{array}{l}\text { Participants } \\
(n=1,407)\end{array}$ & $\begin{array}{l}\text { Non-participants } \\
(n=713)\end{array}$ & Effect Size ${ }^{b}$ \\
\hline \multicolumn{4}{|l|}{ Child } \\
\hline Male, No. (\%) & $665(47.26)$ & $415(58.20)$ & $-0.11^{c}$ \\
\hline Low birth weight $(<2500 \mathrm{~g})$, No. (\%) & $44(3.13)$ & $27(3.79)$ & -0.007 \\
\hline \multicolumn{4}{|l|}{ Family } \\
\hline Socioeconomic status, mean (SD) ${ }^{d}$ & $0.04(0.94)$ & $-0.15(1.01)$ & $-0.20^{c}$ \\
\hline Maternal age at child birth, mean (SD), y & $29.33(5.19)$ & $29.24(5.30)$ & -0.02 \\
\hline Paternal age at child birth, mean (SD), y & $32.26(5.49)$ & $32.26(5.94)$ & 0.001 \\
\hline Family dysfunction score, mean (SD) e & $1.71(1.44)$ & $1.70(1.50)$ & -0.007 \\
\hline No intact family (single or blended), No. (\%) & $251(17.84)$ & $155(21.74)$ & -0.04 \\
\hline \multicolumn{4}{|l|}{ Hostile-reactive parenting score, mean $(S D)^{f}$} \\
\hline Maternal & $2.94(0.96)$ & $2.90(1.10)$ & -0.05 \\
\hline Paternal & $2.59(1.03)$ & $2.58(1.10)$ & -0.005 \\
\hline \multicolumn{4}{|l|}{ Parental mental health, mean (SD) } \\
\hline Maternal depressions & $1.38(1.32)$ & $1.45(1.38)$ & 0.06 \\
\hline Maternal antisociality in adolescence ${ }^{h}$ & $0.21(0.47)$ & $0.23(0.54)$ & 0.05 \\
\hline Paternal depressions & $1.00(0.95)$ & $1.00(0.99)$ & 0.005 \\
\hline Paternal antisociality in adolescence ${ }^{h}$ & $0.57(0.82)$ & $0.51(0.75)$ & -0.08 \\
\hline
\end{tabular}

a All variables were measured when the child was 5 months of age, except 3.5 years for hostile-reactive parenting. Data were compiled from the final master file of the Québec Longitudinal Study of Child Development (1998-2015), Québec Government, Québec Statistics Institute

b Calculated as Cohen's d effect size or success rate difference (very small: <0.20; small: 0.20-0.50; medium: 0.50-0.80; large: 0.80-1.20; very large: 1.20-2.0; huge: > 2.0). $\mathrm{p}$ values are based on unpaired t test or MannWhitney test for continuous variables and $\mathrm{x}^{2}$ test for categorical variables

${ }^{c} \mathrm{p}<0.001$

d Assessed with an aggregate of 5 items regarding parental educational level, parental occupation, and annual gross income (range, -3 to 3 , centered at 0 , with higher scores indicating higher socioeconomic status)

e Assessed with 7 items (e.g., do not get along well together) from McMaster Family Assessment administered to the mother. Scores range from 0 to 10 , with higher scores indicating lower family functioning

${ }^{f}$ Assessed with 8 items (e.g., "When he or she broke the rules or did things that he or she was not supposed to, how often did you use physical punishment?") administered to the parent. Scores range from 0 to 10 , with higher scores indicating high hostile-reactive parenting

g Assessed using a short version of the Center for Epidemiological Study Depression Scale. Scores range from 0 to 10 , with higher scores indicating higher depressive symptoms

${ }^{\mathrm{h}}$ Assessed with binary questions on 5 different conduct problems based on the DSM-IV criteria for conduct disorder and antisocial personality disorder. Scores range from 0 to 5, with higher scores indicating more antisocial behaviors 
Table 2. Characteristic of participants on key variables ${ }^{a}$ by childhood profile of ADHD ${ }^{b}$ and irritability, $n=1,407$, ELDEQ.

\begin{tabular}{|c|c|c|c|c|c|}
\hline Characteristics & $\begin{array}{l}\begin{array}{l}\text { Reference } \\
\text { group }\end{array} \\
(n=940)\end{array}$ & $\begin{array}{l}\text { Moderately } \\
\text { high } \\
\text { irritability } \\
\text { \& low ADHD } \\
(n=158)\end{array}$ & $\begin{array}{l}\text { Moderately } \\
\text { high ADHD } \\
\text { \& low } \\
\text { irritability } \\
(\mathrm{n}=198)\end{array}$ & $\begin{array}{l}\text { Combined } \\
\text { high ADHD } \\
\text { \& high } \\
\text { irritability } \\
(\mathrm{n}=111)\end{array}$ & p-value \\
\hline \multicolumn{6}{|l|}{ Child } \\
\hline Male, No. (\%) & 347 (36.91) & $96(60.76)$ & $133(67.17)$ & $89(80.18)$ & $<0.001$ \\
\hline Low birth weight $(<2500 \mathrm{~g})$, No. $(\%)$ & $30(3.19)$ & $6(3.80)$ & $6(3.03)$ & $2(1.80)$ & 0.32 \\
\hline \multicolumn{6}{|l|}{ Family } \\
\hline Socioeconomic status, mean (SD) ${ }^{d}$ & $0.15(0.94)$ & $-0.07(0.87)$ & $-0.16(0.92)$ & $-0.37(0.92)$ & $<0.001$ \\
\hline Maternal age at child birth, mean (SD), y & $29.65(5.12)$ & $29.26(5.20)$ & $28.82(5.25)$ & $27.62(5.28)$ & $<0.001$ \\
\hline Paternal age at child birth, mean (SD), y & $32.31(5.19)$ & $32.40(6.46)$ & $32.33(5.99)$ & $31.47(5.69)$ & 0.53 \\
\hline Family dysfunction score, mean (SD) & $1.67(1.43)$ & $1.92(1.53)$ & $1.75(1.46)$ & $1.69(1.36)$ & 0.25 \\
\hline $\begin{array}{l}\text { No intact family (single or blended), } \\
\text { No. }(\%)\end{array}$ & $137(14.57)$ & $122(72.22)$ & $155(78.28)$ & $73(65.77)$ & $<0.001$ \\
\hline $\begin{array}{l}\text { Hostile-reactive parenting score, } \\
\text { mean }(S D)^{f}\end{array}$ & & & & & $<0.001$ \\
\hline Maternal & $2.84(0.94)$ & $3.16(0.99)$ & $3.15(0.99)$ & $3.19(0.86)$ & $<0.001$ \\
\hline Paternal & $2.52(1.00)$ & $2.73(1.08)$ & $2.78(1.11)$ & $2.70(0.93)$ & 0.01 \\
\hline \multicolumn{6}{|l|}{ Parental mental health score, mean (SD) } \\
\hline Maternal depressiong & $1.25(1.21)$ & $1.69(1.65)$ & $1.54(1.36)$ & $1.72(1.45)$ & $<0.001$ \\
\hline $\begin{array}{l}\text { Maternal antisociality in } \\
\text { adolescence }\end{array}$ & $0.18(0.43)$ & $0.25(0.55)$ & $0.23(0.49)$ & $0.32(0.58)$ & 0.01 \\
\hline Paternal depressions & $0.98(0.93)$ & $1.12(1.07)$ & $0.97(0.82)$ & $1.08(1.10)$ & 0.34 \\
\hline Paternal antisociality in adolescence ${ }^{\mathrm{h}}$ & $0.53(0.75)$ & $0.78(1.08)$ & $0.60(0.90)$ & $0.64(0.81)$ & 0.01 \\
\hline
\end{tabular}

Note: Profiles "No ADHD and no irritability" and "Low ADHD and very low irritability" were combined and used as the reference group with $n=401(28.50 \%)$ and $n=539(38.31 \%)$, respectively

a Variables were measured when the child was 5 months of age, except 3.5 years for hostile-reactive parenting. Data were compiled from the final master file of the Québec Longitudinal Study of Child Development (1998-2015), Québec Government, Québec Statistics Institute.

${ }^{b}$ ADHD, Attention Deficit Hyperactivity Disorder

c $p$-values are based on ANOVA test for continuous variables and $x^{2}$ test for categorical variables.

${ }^{d}$ Assessed with an aggregate of 5 items regarding parental educational level, parental occupation, and annual gross income (range, -3 to 3 , centered at 0 , with higher scores indicating higher socioeconomic status).

e Assessed with 7 items (e.g., do not get along well together) from McMaster Family Assessment administered to the mother. Scores range from 0 to 10 , with higher scores indicating lower family functioning.

${ }^{f}$ Assessed with 8 items (e.g., "When he or she broke the rules or did things that he or she was not supposed to, how often did you use physical punishment?") administered to the parent. Scores range from 0 to 10, with higher scores indicating high hostile-reactive parenting.

${ }^{\mathrm{g}}$ Assessed using a short version of the Center for Epidemiological Study Depression Scale. Scores range from 0 to 10, with higher scores indicating higher depressive symptoms.

${ }^{\mathrm{h}}$ Assessed with binary questions on 5 different conduct problems based on the DSM-IV criteria for conduct disorder and antisocial personality disorder. Scores range from 0 to 5 , with higher scores indicating more antisocial behaviors 
Table 3. Weighted associations between childhood profiles of ADHDa - Irritability and adolescent psychiatric symptoms, suicidal outcome, and functional impairment. ELDEQ, Multivariate statistics.

\begin{tabular}{|c|c|c|c|c|}
\hline & \multicolumn{4}{|c|}{ Childhood profiles } \\
\hline & $\begin{array}{c}\text { Moderately high } \\
\text { irritability \& low ADHDa }\end{array}$ & $\begin{array}{l}\text { Moderately high ADHDa } \\
\text { \& low irritability }\end{array}$ & $\begin{array}{l}\text { Combined high ADHDa } \\
\text { \& high irritability }\end{array}$ & $\mathrm{p}^{\mathrm{b}}$ \\
\hline & $\begin{array}{c}\text { B or OR } \\
(95 \% \mathrm{Cl}) \\
\text { Effect size }\end{array}$ & $\begin{array}{c}\text { B or OR } \\
(95 \% \mathrm{Cl}) \\
\text { Effect size }\end{array}$ & $\begin{array}{c}\text { B or OR } \\
(95 \% \mathrm{Cl}) \\
\text { Effect size }\end{array}$ & \\
\hline $\begin{array}{l}\text { Total of internalizing } \\
\text { symptoms }\end{array}$ & $\begin{array}{c}0.05 \\
(-0.26,0.36) \\
0.03\end{array}$ & $\begin{array}{c}-0.01 \\
(-0.30,0.27) \\
-0.01\end{array}$ & $\begin{array}{c}0.57 \\
(0.18,0.96) \\
0.29\end{array}$ & * \\
\hline Social phobia & $\begin{array}{c}-0.19 \\
(-0.55,0.18) \\
-0.08\end{array}$ & $\begin{array}{c}-0.17 \\
(-0.51,0.18) \\
-0.07\end{array}$ & $\begin{array}{c}0.60 \\
(0.14,1.07) \\
0.25\end{array}$ & $*$ \\
\hline Generalized anxiety & $\begin{array}{c}0.19 \\
(-0.13,0.52) \\
0.10\end{array}$ & $\begin{array}{c}0.07 \\
(-0.23,0.37) \\
0.03\end{array}$ & $\begin{array}{c}0.57 \\
(0.15,0.98) \\
0.27\end{array}$ & * \\
\hline Depression & $\begin{array}{c}0.12 \\
(-0.23,0.46) \\
0.06\end{array}$ & $\begin{array}{c}0.04 \\
(-0.28,0.36) \\
0.02\end{array}$ & $\begin{array}{c}0.45 \\
(0.01,0.88) \\
0.20\end{array}$ & \\
\hline ADHDa & $\begin{array}{c}0.34 \\
(0.04,0.64) \\
0.19\end{array}$ & $\begin{array}{c}0.43 \\
(0.15,0.71) \\
0.24\end{array}$ & $\begin{array}{c}0.96 \\
(0.58,1.34) \\
0.50\end{array}$ & $* * *$ \\
\hline $\begin{array}{l}\text { Hyperactivity- } \\
\text { Impulsivity }\end{array}$ & $\begin{array}{c}0.37 \\
(0.09,0.65) \\
0.22\end{array}$ & $\begin{array}{c}0.16 \\
(-0.10,0.42) \\
0.10\end{array}$ & $\begin{array}{c}0.72 \\
(0.37,1.08) \\
0.40\end{array}$ & $* * *$ \\
\hline Inattention & $\begin{array}{c}0.26 \\
(-0.06,0.58) \\
0.14\end{array}$ & $\begin{array}{c}0.63 \\
(0.33,0.93) \\
0.32\end{array}$ & $\begin{array}{c}1.03 \\
(0.62,1.44) \\
0.50\end{array}$ & $* * *$ \\
\hline $\begin{array}{l}\text { Total of externalizing } \\
\text { symptoms }\end{array}$ & $\begin{array}{c}0.24 \\
(0.03,0.46) \\
0.19\end{array}$ & $\begin{array}{c}0.28 \\
(0.08,0.48) \\
0.21\end{array}$ & $\begin{array}{c}0.82 \\
(0.55,1.09) \\
0.59\end{array}$ & $* * *$ \\
\hline $\begin{array}{l}\text { Oppositional defiant } \\
\text { disorder }\end{array}$ & $\begin{array}{c}0.37 \\
(0.11,0.64) \\
0.24\end{array}$ & $\begin{array}{c}0.19 \\
(-0.05,0.43) \\
0.12\end{array}$ & $\begin{array}{c}0.93 \\
(0.60,1.26) \\
0.55\end{array}$ & $* * *$ \\
\hline Conduct disorder & $\begin{array}{c}0.05 \\
(-0.16,0.27) \\
0.04\end{array}$ & $\begin{array}{c}0.22 \\
(0.02,0.41) \\
0.17\end{array}$ & $\begin{array}{c}0.55 \\
(0.28,0.82) \\
0.41\end{array}$ & $* * *$ \\
\hline Psychopathy & $\begin{array}{c}-0.07 \\
(-0.34,0.20) \\
-0.04\end{array}$ & $\begin{array}{c}0.24 \\
(-0.01,0.49) \\
0.15\end{array}$ & $\begin{array}{c}0.44 \\
(0.10,0.78) \\
0.25\end{array}$ & * \\
\hline $\begin{array}{l}\text { Delinquency \& contact } \\
\text { with police }\end{array}$ & $\begin{array}{c}-0.02 \\
(-0.15,0.11) \\
-0.03\end{array}$ & $\begin{array}{c}0.18 \\
(0.06,0.30) \\
0.23\end{array}$ & $\begin{array}{c}0.41 \\
(0.24,0.57) \\
0.49\end{array}$ & $* * *$ \\
\hline Aggression & $\begin{array}{c}0.13 \\
(-0.02,0.29) \\
0.14\end{array}$ & $\begin{array}{c}0.05 \\
(-0.09,0.2) \\
0.06\end{array}$ & $\begin{array}{c}0.46 \\
(0.26,0.66) \\
0.45\end{array}$ & $* * *$ \\
\hline Eating disorders & $\begin{array}{c}0.17 \\
(-0.13,0.46) \\
0.10\end{array}$ & $\begin{array}{c}0.05 \\
(-0.22,0.32) \\
0.03\end{array}$ & $\begin{array}{c}0.26 \\
(-0.11,0.63) \\
0.14\end{array}$ & \\
\hline Suicidality $^{d}$ & $\begin{array}{c}1.24 \\
(0.91,1.69) \\
0.12\end{array}$ & $\begin{array}{c}1.50 \\
(1.13,1.98) \\
0.22\end{array}$ & $\begin{array}{c}2.12 \\
(1.47,3.06) \\
0.41\end{array}$ & $* * *$ \\
\hline
\end{tabular}




\begin{tabular}{|c|c|c|c|c|}
\hline Total functional impairment & $\begin{array}{c}0.45 \\
(0.14,0.75) \\
0.25\end{array}$ & $\begin{array}{c}0.28 \\
(-0.01,0.56) \\
0.15\end{array}$ & $\begin{array}{c}0.92 \\
(0.54,1.31) \\
0.47\end{array}$ & $* * *$ \\
\hline $\begin{array}{l}\text { Functional impairment } \\
\text { scale for behavior }\end{array}$ & $\begin{array}{c}0.25 \\
(0.04,0.47) \\
0.20\end{array}$ & $\begin{array}{c}0.18 \\
(-0.02,0.38) \\
0.14\end{array}$ & $\begin{array}{c}0.67 \\
(0.4,0.94) \\
0.48\end{array}$ & $* * *$ \\
\hline $\begin{array}{l}\text { Functional impairment } \\
\text { scale for anxiety }\end{array}$ & $\begin{array}{c}0.46 \\
(0.09,0.82) \\
0.21\end{array}$ & $\begin{array}{c}0.44 \\
(0.11,0.78) \\
0.20\end{array}$ & $\begin{array}{c}0.98 \\
(0.52,1.44) \\
0.42\end{array}$ & $* * *$ \\
\hline $\begin{array}{l}\text { Functional impairment } \\
\text { scale for depression }\end{array}$ & $\begin{array}{c}0.52 \\
(0.16,0.88) \\
0.24\end{array}$ & $\begin{array}{c}0.22 \\
(-0.11,0.56) \\
0.10\end{array}$ & $\begin{array}{c}0.95 \\
(0.49,1.41) \\
0.41\end{array}$ & $* * *$ \\
\hline $\begin{array}{l}\text { Functional impairment } \\
\text { scale for eating disorders }\end{array}$ & $\begin{array}{c}0.15 \\
(-0.08,0.38) \\
0.11\end{array}$ & $\begin{array}{c}0.02 \\
(-0.19,0.24) \\
0.02\end{array}$ & $\begin{array}{c}0.25 \\
(-0.04,0.54) \\
0.17\end{array}$ & \\
\hline
\end{tabular}

Note: Profiles "No ADHD and no irritability" and "Very low ADHD and very low irritability" were combined and used as the reference group with $n=401(28.50 \%)$ and $n=539(38.31 \%)$, respectively. Ns vary between 1,372 and 1,407

Note 2: Adjusted for child's sex, family socioeconomic status, maternal age at child birth, no intact family, maternal and paternal hostile-reactive parenting score, maternal depression, maternal and paternal antisociality in adolescence.

${ }^{a}$ ADHD, Attention Deficit Hyperactivity Disorder

${ }^{b}$ Multiple testing corrected $p$-values using the Benjamini-Hochberg procedure $\left({ }^{*}: p\right.$-value $<0.05,{ }^{* *}: p$-value $<0.01,{ }^{* * *}$ : p-value $<0.001$ )

c Standardized effect size based on Cohen's d statistic (very small: <0.20; small: 0.20-0.50; medium: 0.50-0.80; large: $0.80-1.20$; very large: $1.20-2.0$; huge: > 2.0) or success rate difference

${ }^{d}$ Odds ratios were estimated using logistic regressions 

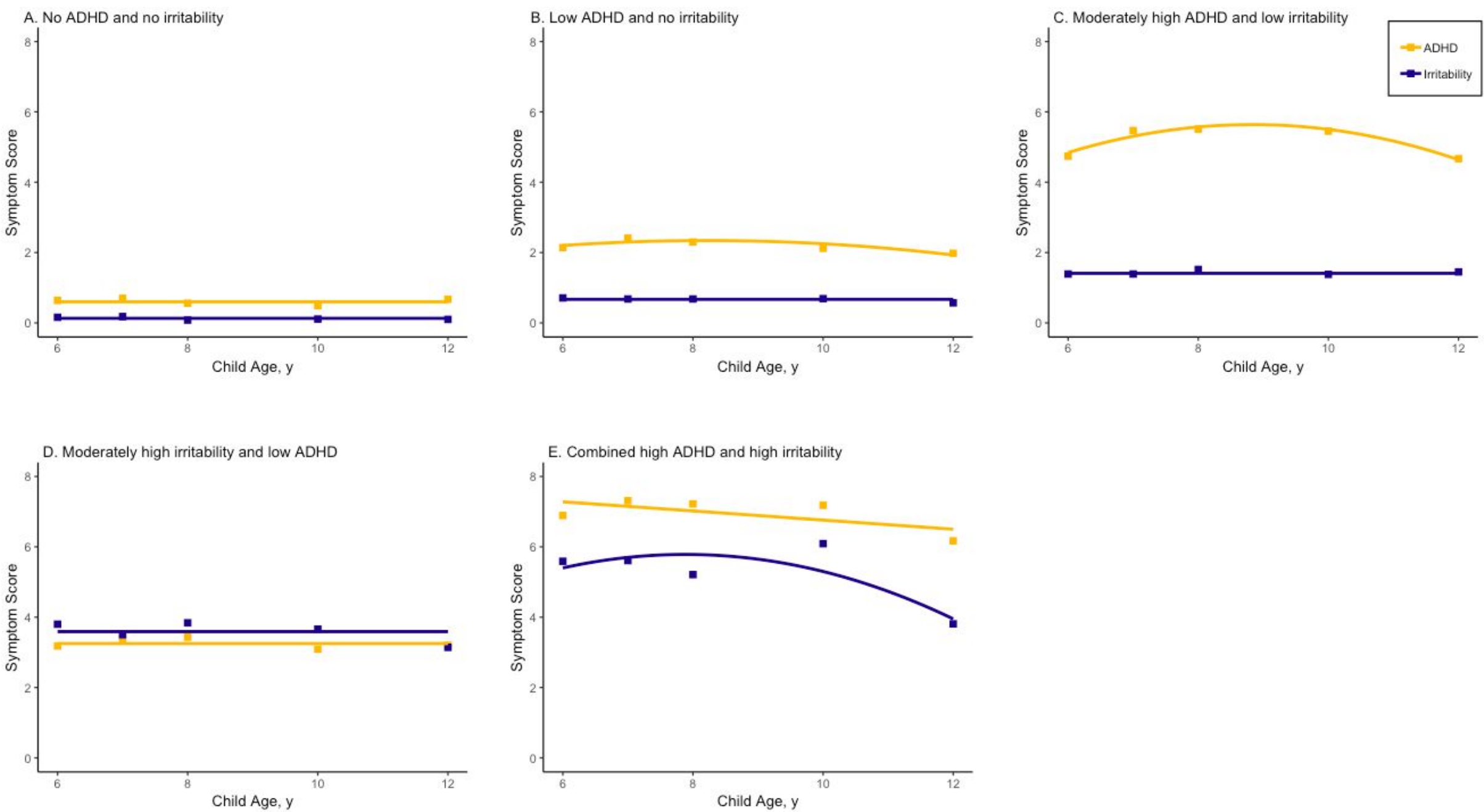

Figure 1. Multi-trajectories of childhood attention deficit hyperactivity disorder (ADHD) and irritability.

Each column represents a different profile in the multi-trajectory model and is defined by the trajectory of attention deficit hyperactivity disorder and irritability at $6,7,8$, 10 , and 12 years of age. Boxes represent observed value, and lines represent the fitted regression slopes 
eTable1. Multitrajectory modeling estimations

\begin{tabular}{lllllllll}
\hline$G$ & B & Entropy & $\begin{array}{c}\text { Groups } \\
\mathrm{n}(\%)\end{array}$ \\
\cline { 3 - 8 } & 1 & 2 & 3 & 4 & 5 & 6
\end{tabular}

$\begin{array}{cccccccccc}4 & -17420.15 & -17490.16 & 82.28 & 408 & 565 & 331 & 103 & & \\ & & & & (29.0) & (40.2) & (23.5) & (7.3) & & \\ \mathbf{5} & \mathbf{- 1 7 3 3 6 . 3 4} & -17424.77 & \mathbf{7 9 . 2 0} & \mathbf{4 0 1} & \mathbf{5 3 9} & \mathbf{1 9 8} & \mathbf{1 5 8} & \mathbf{1 1 1} & \\ & & & & \mathbf{( 2 8 . 5 )} & \mathbf{( 3 8 . 3 )} & \mathbf{( 1 4 . 1 )} & \mathbf{( 1 1 . 2 )} & \mathbf{( 7 . 9 )} & \\ \mathbf{6} & -17269.34 & -17390.93 & 75.63 & 383 & 429 & 210 & 160 & 142 & 83 \\ & & & & (27.2) & (30.5) & (14.9) & (11.4) & (10.1) & (5.9)\end{array}$

Note: G, Number of Groups; L, Log likelihood; BIC, Bayesian Information Criterion

Selected model in bold 
eTable 2. Distribution of adolescent mental health problems ${ }^{\mathrm{a}}$ and suicidal outcorffe ${ }^{\mathrm{P}}$ by childhood profile of ADHD and irritability, ELDEQ.

\section{Childhood profiles}

\begin{tabular}{|c|c|c|c|c|c|c|c|c|c|c|}
\hline \multirow[b]{3}{*}{$\begin{array}{l}\text { Psychopathology scales } \\
\text { n (\%) }\end{array}$} & \multirow{2}{*}{\multicolumn{5}{|c|}{ Girls, n=742 (52.74) }} & \multirow{2}{*}{\multicolumn{5}{|c|}{ Boys, $n=665$ (47.26) }} \\
\hline & & & & & & & & & & \\
\hline & $\begin{array}{l}\text { Reference }^{d} \\
593(79.92)\end{array}$ & $\begin{array}{c}\text { Moderately } \\
\text { high } \\
\text { irritability } \\
\text { \& low } \\
\text { ADHDC } \\
62(8.36)\end{array}$ & $\begin{array}{l}\text { Moderately } \\
\text { high ADHDC } \\
\text { \& low } \\
\text { irritability } \\
65(8.76)\end{array}$ & $\begin{array}{l}\text { Combined } \\
\text { high ADHDC } \\
\text { \& high } \\
\text { irritability } \\
22(2.96)\end{array}$ & pe & $\begin{array}{l}\text { Reference }^{d} \\
347(52.18)\end{array}$ & $\begin{array}{c}\text { Moderately } \\
\text { high } \\
\text { irritability } \\
\text { \& low } \\
\text { ADHDC } \\
96(14.44)\end{array}$ & $\begin{array}{l}\text { Moderately } \\
\text { high ADHDC } \\
\text { \& low } \\
\text { irritability } \\
133(20.00)\end{array}$ & $\begin{array}{l}\text { Combined } \\
\text { high ADHDC } \\
\text { \& high } \\
\text { irritability } \\
89(13.38)\end{array}$ & pe \\
\hline $\begin{array}{l}\text { Total of internalizing } \\
\text { symptoms }\end{array}$ & $4.39(1.79)$ & $4.43(1.73)$ & $4.08(1.56)$ & $5.32(1.89)$ & 0.06 & $2.73(1.53)$ & $2.90(1.59)$ & $3.03(1.61)$ & $3.28(1.80)$ & 0.03 \\
\hline Social phobia & $3.13(2.23)$ & $2.72(1.98)$ & $2.42(1.88)$ & $4.07(2.16)$ & 0.01 & $1.78(1.73)$ & $1.90(1.88)$ & $2.14(1.87)$ & $2.40(2.03)$ & 0.03 \\
\hline Generalized anxiety & $4.92(1.83)$ & $5.25(1.86)$ & $4.93(1.68)$ & $5.93(1.98)$ & 0.06 & $3.26(1.73)$ & 3.39 (1.79) & $3.45(1.72)$ & $3.74(1.93)$ & 0.18 \\
\hline Depression & $4.33(1.98)$ & $4.47(2.15)$ & $4.11(1.70)$ & $5.03(2.28)$ & 0.30 & $2.63(1.75)$ & $2.89(1.80)$ & $2.96(1.91)$ & $3.11(1.95)$ & 0.10 \\
\hline ADHDc & $3.25(1.70)$ & $3.73(1.51)$ & $3.77(1.63)$ & $4.15(1.63)$ & 0.006 & $2.91(1.61)$ & $3.33(1.73)$ & $3.43(1.55)$ & $4.07(1.82)$ & $<0.001$ \\
\hline Hyperactivity- Impulsivity & $2.58(1.53)$ & $3.08(1.44)$ & $2.82(1.66)$ & $3.47(1.63)$ & 0.006 & $2.42(1.55)$ & $2.86(1.73)$ & $2.68(1.61)$ & $3.31(1.91)$ & $<0.001$ \\
\hline $\begin{array}{l}\text { Total of externalizing } \\
\text { symptoms }\end{array}$ & $1.99(1.13)$ & $2.44(1.24)$ & $2.35(1.24)$ & $3.06(1.89$ & $<0.001$ & $1.92(1.23)$ & $2.20(1.21)$ & $2.31(1.25)$ & $2.86(1.75)$ & $<0.001$ \\
\hline $\begin{array}{l}\text { Oppositional defiant } \\
\text { disorder }\end{array}$ & $2.63(1.48)$ & $3.29(1.57)$ & $3.01(1.46)$ & $3.81(1.55)$ & $<0.001$ & $2.55(1.47)$ & $2.93(1.47)$ & $2.83(1.42)$ & $3.64(1.74)$ & $<0.001$ \\
\hline Conduct disorder & $0.94(1.12)$ & $1.28(1.27)$ & $1.21(1.18)$ & $1.74(2.18)$ & 0.005 & $0.92(1.12)$ & $0.93(0.93)$ & $1.25(1.39)$ & $1.55(1.77)$ & $<0.001$ \\
\hline Psychopathy & $3.16(1.37)$ & $2.96(1.50)$ & $3.40(1.45)$ & $4.00(1.62)$ & 0.02 & $3.91(1.66)$ & $4.11(1.62)$ & $4.31(1.70)$ & $4.42(1.74)$ & 0.03 \\
\hline $\begin{array}{l}\text { Delinquency \& contact } \\
\text { with police }\end{array}$ & $0.14(0.50)$ & $0.11(0.29)$ & $0.28(0.74)$ & $0.86(2.32)$ & $<0.001$ & $0.23(0.59)$ & $0.32(0.78)$ & $0.54(1.28)$ & $0.66(1.33)$ & $<0.001$ \\
\hline Aggression & $0.73(0.69)$ & $0.93(0.73)$ & $0.88(1.08)$ & $1.56(1.87)$ & $<0.001$ & $0.92(0.91)$ & $1.15(1.02)$ & $1.01(1.05)$ & $1.38(1.60)$ & 0.006 \\
\hline Eating disorders & $2.23(1.82)$ & $2.49(1.89)$ & $2.29(1.66)$ & $3.47(1.67)$ & 0.02 & $1.21(1.24)$ & $1.50(1.33)$ & $1.42(1.52)$ & $1.33(1.15)$ & 0.19 \\
\hline Total functional impairment & $2.03(1.80)$ & $2.88(2.11)$ & $2.34(1.78)$ & $3.62(2.61)$ & $<0.001$ & $1.07(1.32)$ & $1.28(1.24)$ & $1.40(1.46)$ & $1.83(1.93)$ & $<0.001$ \\
\hline $\begin{array}{l}\text { Functional impairment } \\
\text { scale for anxiety }\end{array}$ & $2.39(2.16)$ & $3.16(2.05)$ & $2.96(2.20)$ & 4.05 (3.09) & 0.001 & $1.27(1.58)$ & $1.46(1.52)$ & 1.67 (1.96) & $2.05(2.10)$ & 0.003 \\
\hline $\begin{array}{l}\text { Functional impairment } \\
\text { scale for eating disorders }\end{array}$ & $0.81(1.47)$ & $1.24(1.92)$ & 0.79 (1.59) & $1.43(1.79)$ & 0.07 & $0.28(0.81)$ & $0.34(0.71)$ & $0.42(0.87)$ & $0.48(1.01)$ & 0.18 \\
\hline
\end{tabular}


Note. Ns vary between 1,372 and 1,407.

a The table reports the descriptive statistics for all the MIA scales, subscales and dimensions (mean / standard deviation). All scores were rescaled to be expressed on a scale from 0 to 10

b Suicidality outcome was measured at ages 13,15 , and 17 years $(\mathrm{n} / \%)$

'ADHD, Attention Deficit Hyperactivity Disorder

d Profiles "No ADHD and no irritability" and "Very low ADHD and very low irritability" were combined and used as the reference group with n=401 ( $28.50 \%$ ) and n=539 (38.31\%), respectively

e $\mathrm{p}$ values are based on ANOVA tests for continuous variables and $\mathrm{x}^{2}$ test for categorical variables (multiple testing corrected $\mathrm{p}$-values using the Benjamini-Hochberg procedure) 
eTable 3. Weighted associations between childhood profiles of ADHDa - Irritabilit $y$ Shhd adolescent psychiatric symptoms, suicidal outcome, and functional impairment stratified by sex, ELDEQ, multivariate statistics.

\begin{tabular}{|c|c|c|c|c|c|c|c|c|}
\hline & \multicolumn{8}{|c|}{ Childhood profiles } \\
\hline & \multicolumn{4}{|c|}{ Girls } & \multicolumn{4}{|c|}{ Boys } \\
\hline & $\begin{array}{c}\text { Moderately high } \\
\text { irritability } \\
\text { \& low ADHD }\end{array}$ & $\begin{array}{l}\text { Moderately high } \\
\text { ADHDa } \\
\text { \& low irritability }\end{array}$ & $\begin{array}{l}\text { Combined high } \\
\mathrm{ADHD}^{\mathrm{a}} \text { \& high } \\
\text { irritability }\end{array}$ & $\mathrm{p}^{\mathrm{b}}$ & $\begin{array}{l}\text { Moderately high } \\
\text { irritability only } \\
\text { \& low ADHDa }\end{array}$ & $\begin{array}{l}\text { Moderately high } \\
\text { ADHDa } \\
\text { \& low irritability }\end{array}$ & $\begin{array}{l}\text { Combined high } \\
\mathrm{ADHD}^{\mathrm{a}} \& \text { high } \\
\text { irritability }\end{array}$ & $\mathrm{p}^{\mathrm{b}}$ \\
\hline & $\begin{array}{l}\text { B or OR }(95 \% \mathrm{Cl}) \\
\text { Effect size }\end{array}$ & $\begin{array}{l}\text { B or OR }(95 \% \mathrm{Cl}) \\
\text { Effect size }\end{array}$ & $\begin{array}{l}\text { B or OR }(95 \% \mathrm{Cl}) \\
\text { Effect size }\end{array}$ & & $\begin{array}{l}\text { B or OR }(95 \% \mathrm{Cl}) \\
\text { Effect size }\end{array}$ & $\begin{array}{l}\text { B or OR }(95 \% \mathrm{Cl}) \\
\text { Effect size }\end{array}$ & $\begin{array}{l}\text { B or OR }(95 \% \mathrm{Cl}) \\
\text { Effect size }\end{array}$ & \\
\hline $\begin{array}{l}\text { Total of internalizing } \\
\text { symptoms }\end{array}$ & $\begin{array}{c}0.01 \\
(-0.48,0.49) \\
0.003\end{array}$ & $\begin{array}{c}-0.36 \\
(-0.85,0.12) \\
-0.19\end{array}$ & $\begin{array}{c}0.87 \\
(0.03,1.72) \\
0.44\end{array}$ & & $\begin{array}{c}0.12 \\
(-0.25,0.49) \\
0.07\end{array}$ & $\begin{array}{c}0.25 \\
(-0.07,0.58) \\
0.15\end{array}$ & $\begin{array}{c}0.52 \\
(0.13,0.92) \\
0.31\end{array}$ & $*$ \\
\hline Social phobia & $\begin{array}{c}-0.37 \\
(-0.97,0.23) \\
-0.16\end{array}$ & $\begin{array}{c}-0.70 \\
(-1.30,-0.11) \\
-0.30\end{array}$ & $\begin{array}{c}0.93 \\
(-0.11,1.97) \\
0.38\end{array}$ & * & $\begin{array}{c}0.08 \\
(-0.35,0.50) \\
0.04\end{array}$ & $\begin{array}{c}0.28 \\
(-0.09,0.66) \\
0.15\end{array}$ & $\begin{array}{c}0.63 \\
(0.18,1.08) \\
0.33\end{array}$ & * \\
\hline $\begin{array}{l}\text { Generalized } \\
\text { anxiety }\end{array}$ & $\begin{array}{c}0.27 \\
(-0.24,0.78) \\
0.14\end{array}$ & $\begin{array}{c}-0.07 \\
(-0.57,0.43) \\
-0.04\end{array}$ & $\begin{array}{c}0.92 \\
(0.04,1.80) \\
0.45\end{array}$ & & $\begin{array}{c}0.11 \\
(-0.3,0.52) \\
0.06\end{array}$ & $\begin{array}{c}0.15 \\
(-0.21,0.52) \\
0.08\end{array}$ & $\begin{array}{c}0.45 \\
(0.01,0.89) \\
0.24\end{array}$ & \\
\hline Depression & $\begin{array}{c}0.07 \\
(-0.48,0.61) \\
0.03\end{array}$ & $\begin{array}{c}-0.31 \\
(-0.85,0.23) \\
-0.15\end{array}$ & $\begin{array}{c}0.62 \\
(-0.32,1.57) \\
0.28\end{array}$ & & $\begin{array}{c}0.18 \\
(-0.25,0.60) \\
0.10\end{array}$ & $\begin{array}{c}0.30 \\
(-0.08,0.68) \\
0.16\end{array}$ & $\begin{array}{c}0.42 \\
(-0.03,0.88) \\
0.22\end{array}$ & \\
\hline $\mathrm{ADHD}^{\mathrm{a}}$ & $\begin{array}{c}0.34 \\
(-0.11,0.80) \\
0.20\end{array}$ & $\begin{array}{c}0.38 \\
(-0.08,0.83) \\
0.21\end{array}$ & $\begin{array}{c}0.64 \\
(-0.15,1.43) \\
0.34\end{array}$ & & $\begin{array}{c}0.35 \\
(-0.03,0.74) \\
0.21\end{array}$ & $\begin{array}{c}0.47 \\
(0.13,0.81) \\
0.27\end{array}$ & $\begin{array}{c}1.07 \\
(0.66,1.48) \\
0.61\end{array}$ & $* * *$ \\
\hline $\begin{array}{l}\text { Hyperactivity- } \\
\text { Impulsivity }\end{array}$ & $\begin{array}{c}0.36 \\
(-0.05,0.78) \\
0.23\end{array}$ & $\begin{array}{c}0.09 \\
(-0.32,0.50) \\
0.05\end{array}$ & $\begin{array}{c}0.61 \\
(-0.11,1.33) \\
0.36\end{array}$ & & $\begin{array}{c}0.39 \\
(0.01,0.77) \\
0.23\end{array}$ & $\begin{array}{c}0.22 \\
(-0.12,0.56) \\
0.13\end{array}$ & $\begin{array}{c}0.77 \\
(0.36,1.17) \\
0.44\end{array}$ & $* * *$ \\
\hline Inattention & $\begin{array}{c}0.27 \\
(-0.24,0.77) \\
0.14\end{array}$ & $\begin{array}{c}0.60 \\
(0.10,1.10) \\
0.31\end{array}$ & $\begin{array}{c}0.55 \\
(-0.33,1.43) \\
0.27\end{array}$ & & $\begin{array}{c}0.26 \\
(-0.14,0.66) \\
0.15\end{array}$ & $\begin{array}{c}0.63 \\
(0.28,0.99) \\
0.36\end{array}$ & $\begin{array}{c}1.20 \\
(0.77,1.63) \\
0.66\end{array}$ & $* * *$ \\
\hline $\begin{array}{l}\text { Total of externalizing } \\
\text { symptoms }\end{array}$ & $\begin{array}{c}0.32 \\
(0.01,0.63) \\
0.26\end{array}$ & $\begin{array}{c}0.21 \\
(-0.10,0.52) \\
0.18\end{array}$ & $\begin{array}{c}0.83 \\
(0.29,1.38) \\
0.65\end{array}$ & $* *$ & $\begin{array}{c}0.16 \\
(-0.14,0.46) \\
0.12\end{array}$ & $\begin{array}{c}0.31 \\
(0.04,0.58) \\
0.23\end{array}$ & $\begin{array}{c}0.81 \\
(0.49,1.13) \\
0.59\end{array}$ & $* * *$ \\
\hline $\begin{array}{l}\text { Oppositional } \\
\text { defiant disorder }\end{array}$ & $\begin{array}{c}0.48 \\
(0.08,0.88) \\
0.32\end{array}$ & $\begin{array}{c}0.20 \\
(-0.20,0.59) \\
0.13\end{array}$ & $\begin{array}{c}0.83 \\
(0.14,1.51) \\
0.51\end{array}$ & * & $\begin{array}{c}0.24 \\
(-0.10,0.59) \\
0.16\end{array}$ & $\begin{array}{c}0.16 \\
(-0.15,0.46) \\
0.10\end{array}$ & $\begin{array}{c}0.91 \\
(0.55,1.28) \\
0.58\end{array}$ & $* * *$ \\
\hline Conduct disorder & $\begin{array}{c}0.23 \\
(-0.09,0.55) \\
0.19\end{array}$ & $\begin{array}{c}0.14 \\
(-0.17,0.46) \\
0.12\end{array}$ & $\begin{array}{c}0.65 \\
(0.10,1.20) \\
0.50\end{array}$ & & $\begin{array}{c}-0.13 \\
(-0.41,0.16) \\
-0.10\end{array}$ & $\begin{array}{c}0.25 \\
(0.01,0.50) \\
0.20\end{array}$ & $\begin{array}{c}0.51 \\
(0.20,0.81) \\
0.39\end{array}$ & $* *$ \\
\hline
\end{tabular}




\begin{tabular}{|c|c|c|c|c|c|c|c|c|}
\hline $\begin{array}{l}36 \\
\text { Psychopathy }\end{array}$ & $\begin{array}{c}-0.27 \\
(-0.65,0.11) \\
-0.19\end{array}$ & $\begin{array}{c}0.17 \\
(-0.20,0.55) \\
0.12\end{array}$ & $\begin{array}{c}0.69 \\
(0.03,1.35) \\
0.45\end{array}$ & PP & $\begin{array}{c}0.14 \\
(-0.25,0.52) \\
0.08\end{array}$ & $\begin{array}{c}0.32 \\
(-0.02,0.66) \\
0.19\end{array}$ & $\begin{array}{c}0.41 \\
(-0.01,0.82) \\
0.23\end{array}$ & \\
\hline $\begin{array}{l}\text { Delinquency \& } \\
\text { contact with police }\end{array}$ & $\begin{array}{c}-0.08 \\
(-0.24,0.08) \\
-0.13\end{array}$ & $\begin{array}{c}0.06 \\
(-0.10,0.22) \\
0.09\end{array}$ & $\begin{array}{c}0.63 \\
(0.35,0.90) \\
0.96\end{array}$ & $* *$ & $\begin{array}{c}0.03 \\
(-0.17,0.24) \\
0.04\end{array}$ & $\begin{array}{c}0.28 \\
(0.09,0.46) \\
0.30\end{array}$ & $\begin{array}{c}0.37 \\
(0.15,0.59) \\
0.39\end{array}$ & $* * *$ \\
\hline Aggression & $\begin{array}{c}0.12 \\
(-0.09,0.33) \\
0.15\end{array}$ & $\begin{array}{c}0.08 \\
(-0.12,0.29) \\
0.10\end{array}$ & $\begin{array}{c}0.69 \\
(0.33,1.05) \\
0.82\end{array}$ & $* *$ & $\begin{array}{c}0.12 \\
(-0.12,0.36) \\
0.11\end{array}$ & $\begin{array}{c}0.03 \\
(-0.18,0.25) \\
0.03\end{array}$ & $\begin{array}{c}0.40 \\
(0.14,0.66) \\
0.36\end{array}$ & $*$ \\
\hline Suicidality ${ }^{d}$ & $\begin{array}{c}1.06 \\
(0.72,1.57) \\
0.03\end{array}$ & $\begin{array}{c}0.89 \\
(0.60,1.33) \\
-0.06\end{array}$ & $\begin{array}{c}2.39 \\
(1.40,4.10) \\
0.48\end{array}$ & * & $\begin{array}{c}1.80 \\
(1.01,3.20) \\
0.32\end{array}$ & $\begin{array}{c}3.35 \\
(2.11,5.33) \\
0.67\end{array}$ & $\begin{array}{c}2.42 \\
(1.38,4.24) \\
0.49\end{array}$ & $* * *$ \\
\hline $\begin{array}{l}\text { Total functional } \\
\text { impairment scale }\end{array}$ & $\begin{array}{c}0.72 \\
(0.21,1.22) \\
0.37\end{array}$ & $\begin{array}{c}0.15 \\
(-0.35,0.65) \\
0.08\end{array}$ & $\begin{array}{c}1.41 \\
(0.54,2.28) \\
0.69\end{array}$ & $* *$ & $\begin{array}{c}0.12 \\
(-0.21,0.46) \\
0.08\end{array}$ & $\begin{array}{c}0.28 \\
(-0.01,0.58) \\
0.19\end{array}$ & $\begin{array}{c}0.73 \\
(0.37,1.09) \\
0.48\end{array}$ & $* * *$ \\
\hline $\begin{array}{l}\text { Functional } \\
\text { impairment scale } \\
\text { for anxiety }\end{array}$ & $\begin{array}{c}0.72 \\
(0.12,1.32) \\
0.32\end{array}$ & $\begin{array}{c}0.46 \\
(-0.13,1.06) \\
0.20\end{array}$ & $\begin{array}{c}1.49 \\
(0.45,2.52) \\
0.61\end{array}$ & $* *$ & $\begin{array}{c}0.12 \\
(-0.29,0.52) \\
0.07\end{array}$ & $\begin{array}{c}0.35 \\
(-0.01,0.71) \\
0.19\end{array}$ & $\begin{array}{c}0.75 \\
(0.32,1.18) \\
0.41\end{array}$ & $* *$ \\
\hline $\begin{array}{l}\text { Functional } \\
\text { impairment scale } \\
\text { for depression }\end{array}$ & $\begin{array}{c}0.83 \\
(0.24,1.43) \\
0.37\end{array}$ & $\begin{array}{c}0.03 \\
(-0.56,0.62) \\
0.01\end{array}$ & $\begin{array}{c}1.73 \\
(0.71,2.76) \\
0.72\end{array}$ & $* *$ & $\begin{array}{c}0.13 \\
(-0.26,0.53) \\
0.08\end{array}$ & $\begin{array}{c}0.24 \\
(-0.11,0.59) \\
0.14\end{array}$ & $\begin{array}{c}0.66 \\
(0.24,1.08) \\
0.36\end{array}$ & $*$ \\
\hline $\begin{array}{l}\text { Functional } \\
\text { impairment scale for } \\
\text { eating disorders }\end{array}$ & $\begin{array}{c}0.26 \\
(-0.15,0.68) \\
0.16\end{array}$ & $\begin{array}{c}-0.15 \\
(-0.56,0.26) \\
-0.09\end{array}$ & $\begin{array}{c}0.57 \\
(-0.15,1.29) \\
0.34\end{array}$ & & $\begin{array}{c}0.02 \\
(-0.17,0.22) \\
0.03\end{array}$ & $\begin{array}{c}0.11 \\
(-0.06,0.28) \\
0.13\end{array}$ & $\begin{array}{c}0.15 \\
(-0.05,0.36) \\
0.17\end{array}$ & \\
\hline
\end{tabular}

Note: Profiles "No ADHD and no irritability" and "Very low ADHD and very low irritability" were combined and used as the reference group with n=401 (28.50\%) and $\mathrm{n}=539(38.31 \%)$, respectively. Ns vary between 1,372 and 1,407

Note 2: Adjusted for child's sex, family socioeconomic status, maternal age at child birth, no intact family, maternal and paternal hostile-reactive parenting score, maternal depression, maternal and paternal antisociality in adolescence.

${ }^{a} \mathrm{ADHD}$, Attention Deficit Hyperactivity Disorder

b Multiple testing corrected p-values using the Benjamini-Hochberg procedure $\left({ }^{*}:\right.$ p-value $<0.05,{ }^{, *}:$ p-value $<0.01,{ }^{* * * *}: p$-value $\left.<0.001\right)$

c Standardized effect size based on Cohen's d statistic (very small: <0.20; small: 0.20-0.50; medium: 0.50-0.80; large: 0.80-1.20; very large: 1.20-2.0; huge: > 2.0) or success rate difference

d Odds ratios were estimated using logistic regressions 
eTable 4. Weighted associations between childhood profiles of ADHDa - Irritabilit $y$ Sh impairment (between profiles comparisons of the various ADHD - Irritability groups). ELDEQ, multivariate statistics.

\begin{tabular}{|c|c|c|c|}
\hline & \multicolumn{3}{|c|}{ Childhood profiles } \\
\hline & $\begin{array}{c}\text { Combined high } A_{D H D} \text { \& } \\
\text { high irritability } \\
\text { vs. } \\
\text { Moderately high ADHD } \\
\text { \& low irritability }\end{array}$ & $\begin{array}{c}\text { Combined high } A_{D H D} \text { \& high } \\
\text { irritability } \\
\text { Vs. } \\
\text { Moderately high irritability \& } \\
\text { low ADHD }\end{array}$ & $\begin{array}{c}\text { Moderately high ADHDa } \\
\text { \& low irritability } \\
\text { vs. } \\
\text { Moderately high } \\
\text { irritability \& low ADHD }\end{array}$ \\
\hline & $\begin{array}{l}\text { B or OR }(95 \% \mathrm{Cl}) \\
\text { Effect size }\end{array}$ & $\begin{array}{l}\text { B or OR }(95 \% \mathrm{Cl}) \\
\text { Effect size }\end{array}$ & $\begin{array}{l}\text { B or OR }(95 \% \mathrm{Cl}) \\
\text { Effect size }\end{array}$ \\
\hline $\begin{array}{l}\text { Total of internalizing } \\
\text { symptoms }\end{array}$ & $\begin{array}{c}0.58 \\
(0.14,1.02) \\
0.31\end{array}$ & $\begin{array}{c}0.52 \\
(0.07,0.97) \\
0.28\end{array}$ & $\begin{array}{c}-0.06 \\
(-0.44,0.31) \\
-0.03\end{array}$ \\
\hline Social phobia & $\begin{array}{c}0.77 \\
(0.24,1.3) \\
0.34\end{array}$ & $\begin{array}{c}0.79 \\
(0.24,1.34) \\
0.35\end{array}$ & $\begin{array}{c}0.02 \\
(-0.43,0.47) \\
0.01\end{array}$ \\
\hline Generalized anxiety & $\begin{array}{c}0.50 \\
(0.03,0.96) \\
0.25\end{array}$ & $\begin{array}{c}0.37 \\
(-0.11,0.85) \\
0.19\end{array}$ & $\begin{array}{c}-0.12 \\
(-0.52,0.27) \\
-0.07\end{array}$ \\
\hline Depression & $\begin{array}{c}0.40 \\
(-0.09,0.9) \\
0.19\end{array}$ & $\begin{array}{c}0.33 \\
(-0.18,0.84) \\
0.16\end{array}$ & $\begin{array}{c}-0.07 \\
(-0.5,0.35) \\
-0.04\end{array}$ \\
\hline ADHD & $\begin{array}{c}0.53 \\
(0.11,0.95) \\
0.29\end{array}$ & $\begin{array}{c}0.62 \\
(0.18,1.06) \\
0.34\end{array}$ & $\begin{array}{c}0.09 \\
(-0.28,0.45) \\
0.05\end{array}$ \\
\hline $\begin{array}{l}\text { Hyperactivity- } \\
\text { Impulsivity }\end{array}$ & $\begin{array}{c}0.56 \\
(0.16,0.96) \\
0.33\end{array}$ & $\begin{array}{c}0.36 \\
(-0.06,0.77) \\
0.21\end{array}$ & $\begin{array}{c}-0.20 \\
(-0.55,0.14) \\
-0.12\end{array}$ \\
\hline Inattention & $\begin{array}{c}0.41 \\
(-0.05,0.87) \\
0.21\end{array}$ & $\begin{array}{c}0.77 \\
(0.3,1.25) \\
0.39\end{array}$ & $\begin{array}{c}0.37 \\
(-0.03,0.76) \\
0.19\end{array}$ \\
\hline $\begin{array}{l}\text { Total of externalizing } \\
\text { symptoms }\end{array}$ & $\begin{array}{c}0.54 \\
(0.24,0.85) \\
0.41\end{array}$ & $\begin{array}{c}0.58 \\
(0.26,0.9) \\
0.44\end{array}$ & $\begin{array}{c}0.03 \\
(-0.23,0.3) \\
0.03\end{array}$ \\
\hline $\begin{array}{l}\text { Oppositional defiant } \\
\text { disorder }\end{array}$ & $\begin{array}{c}0.74 \\
(0.37,1.12) \\
0.46\end{array}$ & $\begin{array}{c}0.56 \\
(0.17,0.95) \\
0.35\end{array}$ & $\begin{array}{c}-0.18 \\
(-0.51,0.14) \\
-0.12\end{array}$ \\
\hline Conduct disorder & $\begin{array}{c}0.34 \\
(0.03,0.64) \\
0.26\end{array}$ & $\begin{array}{c}0.50 \\
(0.18,0.82) \\
0.39\end{array}$ & $\begin{array}{c}0.16 \\
(-0.1,0.42) \\
0.13\end{array}$ \\
\hline
\end{tabular}




\begin{tabular}{|c|c|c|c|}
\hline Psychopathy & $\begin{array}{c}0.20 \\
(-0.19,0.58) \\
0.12\end{array}$ & $\begin{array}{c}0.51 \\
(0.11,0.91) \\
0.31\end{array}$ & $\begin{array}{c}0.31 \\
(-0.02,0.64) \\
0.20\end{array}$ \\
\hline $\begin{array}{l}\text { Delinquency \& } \\
\text { contact with police }\end{array}$ & $\begin{array}{c}0.23 \\
(0.04,0.41) \\
0.28\end{array}$ & $\begin{array}{c}0.43 \\
(0.23,0.62) \\
0.54\end{array}$ & $\begin{array}{c}0.20 \\
(0.04,0.36) \\
0.27\end{array}$ \\
\hline Aggression & $\begin{array}{c}0.41 \\
(0.18,0.64) \\
0.42\end{array}$ & $\begin{array}{c}0.33 \\
(0.09,0.56) \\
0.34\end{array}$ & $\begin{array}{c}-0.08 \\
(-0.28,0.11) \\
-0.09\end{array}$ \\
\hline Eating disorders & $\begin{array}{c}0.21 \\
(-0.21,0.63) \\
0.12\end{array}$ & $\begin{array}{c}0.09 \\
(-0.34,0.53) \\
0.05\end{array}$ & $\begin{array}{c}-0.12 \\
(-0.48,0.24) \\
-0.07\end{array}$ \\
\hline Suicidality ${ }^{d}$ & $\begin{array}{c}1.42 \\
(0.94,2.13) \\
0.19\end{array}$ & $\begin{array}{c}1.71 \\
(1.11,2.65) \\
0.30\end{array}$ & $\begin{array}{c}1.21 \\
(0.83,1.76) \\
0.11\end{array}$ \\
\hline Total functional impairment & $\begin{array}{c}0.65 \\
(0.21,1.08) \\
0.34\end{array}$ & $\begin{array}{c}0.48 \\
(0.02,0.93) \\
0.26\end{array}$ & $\begin{array}{c}-0.17 \\
(-0.54,0.21) \\
-0.09\end{array}$ \\
\hline $\begin{array}{l}\text { Functional impairment } \\
\text { scale for behavior }\end{array}$ & $\begin{array}{c}0.48 \\
(0.18,0.79) \\
0.37\end{array}$ & $\begin{array}{c}0.41 \\
(0.1,0.73) \\
0.32\end{array}$ & $\begin{array}{c}-0.07 \\
(-0.33,0.19) \\
-0.06\end{array}$ \\
\hline $\begin{array}{l}\text { Functional impairment } \\
\text { scale for anxiety }\end{array}$ & $\begin{array}{c}0.54 \\
(0.02,1.05) \\
0.24\end{array}$ & $\begin{array}{c}0.52 \\
(-0.02,1.06) \\
0.24\end{array}$ & $\begin{array}{c}-0.01 \\
(-0.46,0.43) \\
-0.01\end{array}$ \\
\hline $\begin{array}{l}\text { Functional impairment } \\
\text { scale for depression }\end{array}$ & $\begin{array}{c}0.73 \\
(0.21,1.24) \\
0.33\end{array}$ & $\begin{array}{c}0.43 \\
(-0.1,0.96) \\
0.20\end{array}$ & $\begin{array}{c}-0.30 \\
(-0.74,0.15) \\
-0.14\end{array}$ \\
\hline $\begin{array}{l}\text { Functional impairment } \\
\text { scale for eating disorders }\end{array}$ & $\begin{array}{c}0.23 \\
(-0.11,0.56) \\
0.16\end{array}$ & $\begin{array}{c}0.10 \\
(-0.24,0.44) \\
0.07\end{array}$ & $\begin{array}{c}-0.12 \\
(-0.41,0.16) \\
-0.09\end{array}$ \\
\hline
\end{tabular}

Note: Profiles "No ADHD and no irritability" and "Very low ADHD and very low irritability" were combined and used as the reference group with n=401 (28.50\%) and $\mathrm{n}=539(38.31 \%)$, respectively. Ns vary between 1,372 and 1,407

Note 2: Adjusted for child's sex, family socioeconomic status, maternal age at child birth, no intact family, maternal and paternal hostile-reactive parenting score, maternal depression, maternal and paternal antisociality in adolescence.

a ADHD, Attention Deficit Hyperactivity Disorder

b Multiple testing corrected p-values using the Benjamini-Hochberg procedure (": p-value $<0.05,{ }^{\text {,** }}: \mathrm{p}$-value $<0.01,{ }^{* * * *}: \mathrm{p}$-value $\left.<0.001\right)$

c Standardized effect size based on Cohen's d statistic (very small: <0.20; small: 0.20-0.50; medium: 0.50-0.80; large: 0.80-1.20; very large: 1.20-2.0; huge: > 2.0) or success rate difference

d Odds ratios were estimated using logistic regressions 
eTable 5. Associations (unweighted) between childhood profiles of ADHDa - Irritability and adolescent psychiatric symptoms and suicidal outcome, ELDEQ, Page 34 of 36 Multivariate statistics.

\begin{tabular}{|c|c|c|c|c|c|c|c|c|c|c|c|c|}
\hline & \multicolumn{12}{|c|}{ Childhood profiles } \\
\hline & \multicolumn{4}{|c|}{ All } & \multicolumn{4}{|c|}{ Girls } & \multicolumn{4}{|c|}{ Boys } \\
\hline & $\begin{array}{c}\text { Moderately } \\
\text { high } \\
\text { irritability } \\
\& \text { low ADHD }\end{array}$ & $\begin{array}{c}\text { Moderately } \\
\text { high ADHD } \\
\text { \& low } \\
\text { irritability }\end{array}$ & $\begin{array}{l}\text { Combined } \\
\text { high ADHDa } \\
\text { \& high } \\
\text { irritability }\end{array}$ & $\mathrm{p}^{\mathrm{b}}$ & $\begin{array}{c}\text { Moderately } \\
\text { high } \\
\text { irritability } \\
\text { \& low ADHDa }\end{array}$ & $\begin{array}{l}\text { Moderately } \\
\text { high ADHDa } \\
\text { \& low } \\
\text { irritability }\end{array}$ & $\begin{array}{l}\text { Combined } \\
\text { high ADHDa } \\
\text { \& high } \\
\text { irritability }\end{array}$ & $\mathrm{p}^{\mathrm{b}}$ & $\begin{array}{c}\text { Moderately } \\
\text { high } \\
\text { irritability } \\
\text { \& low ADHD }\end{array}$ & $\begin{array}{c}\text { Moderately } \\
\text { high ADHD } \\
\text { \& low } \\
\text { irritability }\end{array}$ & $\begin{array}{l}\text { Combined } \\
\text { high ADHDa } \\
\text { \& high } \\
\text { irritability }\end{array}$ & $\mathrm{p}^{\mathrm{b}}$ \\
\hline & $\begin{array}{c}\text { B or OR } \\
(95 \% \mathrm{Cl}) \\
\text { Effect sizec }\end{array}$ & $\begin{array}{c}\text { B or OR } \\
(95 \% \mathrm{Cl}) \\
\text { Effect sizec }\end{array}$ & $\begin{array}{c}\text { B or OR } \\
(95 \% \mathrm{Cl}) \\
\text { Effect size }\end{array}$ & & $\begin{array}{c}\text { B or OR } \\
(95 \% \mathrm{Cl}) \\
\text { Effect sizec }\end{array}$ & $\begin{array}{c}\text { B or OR }(95 \% \mathrm{Cl}) \\
\text { Effect size }\end{array}$ & $\begin{array}{c}\text { B or OR } \\
(95 \% \mathrm{Cl}) \\
\text { Effect sizec }\end{array}$ & & $\begin{array}{c}\text { B or OR } \\
(95 \% \mathrm{Cl}) \\
\text { Effect size }\end{array}$ & $\begin{array}{c}\text { B or OR } \\
(95 \% \mathrm{Cl}) \\
\text { Effect sizec }\end{array}$ & $\begin{array}{c}\text { B or OR } \\
(95 \% \mathrm{Cl}) \\
\text { Effect sizec }\end{array}$ & \\
\hline $\begin{array}{l}\text { Total of } \\
\text { internalizing } \\
\text { symptoms }\end{array}$ & $\begin{array}{c}0.06 \\
(-0.24 \\
0.35) \\
0.03\end{array}$ & $\begin{array}{c}0.04 \\
(-0.23,0.31) \\
0.02\end{array}$ & $\begin{array}{c}0.56 \\
(0.21 \\
0.92) \\
0.31\end{array}$ & * & $\begin{array}{c}0.02 \\
(-0.46 \\
0.51) \\
0.01\end{array}$ & $\begin{array}{c}-0.37 \\
(-0.84,0.10) \\
-0.20\end{array}$ & $\begin{array}{c}0.88 \\
(0.10 \\
1.67) \\
0.48\end{array}$ & & $\begin{array}{c}0.11 \\
(-0.26 \\
0.48) \\
0.07\end{array}$ & $\begin{array}{c}0.27 \\
(-0.05 \\
0.60) \\
0.17\end{array}$ & $\begin{array}{c}0.53 \\
(0.14,0.92) \\
0.32\end{array}$ & * \\
\hline Social phobia & $\begin{array}{c}-0.15 \\
(-0.51 \\
0.20) \\
-0.07\end{array}$ & $\begin{array}{c}-0.06 \\
(-0.39,0.26) \\
-0.03\end{array}$ & $\begin{array}{c}0.61 \\
(0.18 \\
1.04) \\
0.28\end{array}$ & $*$ & $\begin{array}{c}-0.36 \\
(-0.95 \\
0.23) \\
-0.16\end{array}$ & $\begin{array}{l}-0.71 \\
(-1.29 \\
-0.13) \\
-0.31\end{array}$ & $\begin{array}{c}0.95 \\
(-0.02 \\
1.92) \\
0.42\end{array}$ & $*$ & $\begin{array}{c}0.08 \\
(-0.35 \\
0.50) \\
0.04\end{array}$ & $\begin{array}{c}0.35 \\
(-0.02 \\
0.73) \\
0.19\end{array}$ & $\begin{array}{c}0.65 \\
(0.20,1.09) \\
0.34\end{array}$ & * \\
\hline $\begin{array}{l}\text { Generalized } \\
\text { anxiety }\end{array}$ & $\begin{array}{c}0.16 \\
(-0.16 \\
0.47) \\
0.08\end{array}$ & $\begin{array}{c}0.09 \\
(-0.20,0.38) \\
0.05\end{array}$ & $\begin{array}{c}0.56 \\
(0.19 \\
0.94) \\
0.29\end{array}$ & $*$ & $\begin{array}{c}0.29 \\
(-0.2,0.79) \\
0.15\end{array}$ & $\begin{array}{c}-0.05 \\
(-0.54,0.43) \\
-0.03\end{array}$ & $\begin{array}{c}0.96 \\
(0.14 \\
1.77) \\
0.50\end{array}$ & & $\begin{array}{c}0.06 \\
(-0.36 \\
0.47) \\
0.03\end{array}$ & $\begin{array}{c}0.15 \\
(-0.21 \\
0.52) \\
0.08\end{array}$ & $\begin{array}{c}0.46 \\
(0.03,0.89) \\
0.25\end{array}$ & \\
\hline Depression & $\begin{array}{c}0.15 \\
(-0.19 \\
0.48) \\
0.07\end{array}$ & $\begin{array}{c}0.07 \\
(-0.24,0.38) \\
0.03\end{array}$ & $\begin{array}{c}0.43 \\
(0.02 \\
0.83) \\
0.21\end{array}$ & & $\begin{array}{c}0.09 \\
(-0.45 \\
0.62) \\
0.04\end{array}$ & $\begin{array}{c}-0.34 \\
(-0.86,0.19) \\
-0.16\end{array}$ & $\begin{array}{c}0.59 \\
(-0.29 \\
1.47) \\
0.29\end{array}$ & & $\begin{array}{c}0.21 \\
(-0.21 \\
0.64) \\
0.11\end{array}$ & $\begin{array}{c}0.29 \\
(-0.08 \\
0.67) \\
0.16\end{array}$ & $\begin{array}{c}0.43 \\
(-0.02,0.87) \\
0.22\end{array}$ & \\
\hline $\mathrm{ADHD}^{\mathrm{a}}$ & $\begin{array}{c}0.34 \\
(0.05 \\
0.63) \\
0.20\end{array}$ & $\begin{array}{c}0.41 \\
(0.15,0.68) \\
0.24\end{array}$ & $\begin{array}{c}0.97 \\
(0.62 \\
1.32) \\
0.55\end{array}$ & $* * *$ & $\begin{array}{c}0.34 \\
(-0.11 \\
0.79) \\
0.20\end{array}$ & $\begin{array}{c}0.35 \\
(-0.10,0.79) \\
0.20\end{array}$ & $\begin{array}{c}0.66 \\
(-0.08 \\
1.39) \\
0.38\end{array}$ & & $\begin{array}{c}0.36 \\
(-0.03 \\
0.74) \\
0.21\end{array}$ & $\begin{array}{c}0.45 \\
(0.11 \\
0.79) \\
0.27\end{array}$ & $\begin{array}{c}1.07 \\
(0.66,1.47) \\
0.62\end{array}$ & $* * *$ \\
\hline $\begin{array}{l}\text { Hyperactivity- } \\
\text { Impulsivity }\end{array}$ & $\begin{array}{c}0.36 \\
(0.08 \\
0.63) \\
0.22\end{array}$ & $\begin{array}{c}0.15 \\
(-0.11,0.40) \\
0.09\end{array}$ & $\begin{array}{c}0.74 \\
(0.41 \\
1.07) \\
0.44\end{array}$ & $* * *$ & $\begin{array}{c}0.36 \\
(-0.06 \\
0.77) \\
0.23\end{array}$ & $\begin{array}{c}0.07 \\
(-0.34,0.47) \\
0.04\end{array}$ & $\begin{array}{c}0.64 \\
(-0.04 \\
1.32) \\
0.40\end{array}$ & & $\begin{array}{c}0.38 \\
(0.00,0.75) \\
0.23\end{array}$ & $\begin{array}{c}0.20 \\
(-0.14 \\
0.53) \\
0.12\end{array}$ & $\begin{array}{c}0.77 \\
(0.37,1.17) \\
0.45\end{array}$ & $* *$ \\
\hline
\end{tabular}




\begin{tabular}{|c|c|c|c|c|c|c|c|c|c|c|c|c|c|}
\hline $\begin{array}{l}\text { Pag } \\
1\end{array}$ & $\begin{array}{l}5 \text { of } 36 \\
\text { Total of } \\
\text { externalizing } \\
\text { symptoms }\end{array}$ & $\begin{array}{c}0.24 \\
(0.03 \\
0.45) \\
0.19\end{array}$ & $\begin{array}{c}0.27 \\
(0.08,0.47) \\
0.21\end{array}$ & $\begin{array}{c}0.82 \\
(0.56 \\
1.08) \\
0.63\end{array}$ & $* * *$ & $\begin{array}{c}0.32 \\
(0.00,0.63) \\
0.26\end{array}$ & $\begin{array}{c}\text { JCPP } \\
0.19 \\
(-0.11,0.50) \\
0.16\end{array}$ & $\begin{array}{c}0.84 \\
(0.33 \\
1.36) \\
0.70\end{array}$ & $* *$ & $\begin{array}{c}0.18 \\
(-0.12 \\
0.48) \\
0.14\end{array}$ & $\begin{array}{c}0.31 \\
(0.04 \\
0.58) \\
0.23\end{array}$ & $\begin{array}{c}0.82 \\
(0.50,1.14) \\
0.60\end{array}$ & $* * *$ \\
\hline $\begin{array}{l}3 \\
4 \\
5 \\
6\end{array}$ & $\begin{array}{l}\text { Oppositional } \\
\text { defiant } \\
\text { disorder }\end{array}$ & $\begin{array}{c}0.36 \\
(0.11 \\
0.62) \\
0.24\end{array}$ & $\begin{array}{c}0.18 \\
(-0.06,0.42) \\
0.12\end{array}$ & $\begin{array}{c}0.92 \\
(0.61 \\
1.23) \\
0.59\end{array}$ & $* * *$ & $\begin{array}{c}0.48 \\
(0.08 \\
0.87) \\
0.32\end{array}$ & $\begin{array}{c}0.17 \\
(-0.22,0.56) \\
0.11\end{array}$ & $\begin{array}{c}0.83 \\
(0.18 \\
1.48) \\
0.55\end{array}$ & $*$ & $\begin{array}{c}0.26 \\
(-0.08 \\
0.61) \\
0.17\end{array}$ & $\begin{array}{c}0.16 \\
(-0.14 \\
0.47) \\
0.11\end{array}$ & $\begin{array}{c}0.90 \\
(0.54,1.27) \\
0.58\end{array}$ & $* * *$ \\
\hline $\begin{array}{l}7 \\
8 \\
9 \\
10\end{array}$ & $\begin{array}{l}\text { Conduct } \\
\text { disorder }\end{array}$ & $\begin{array}{c}0.04 \\
(-0.17 \\
0.25) \\
0.03\end{array}$ & $\begin{array}{c}0.22 \\
(0.03,0.42) \\
0.18\end{array}$ & $\begin{array}{c}0.56 \\
(0.30 \\
0.81) \\
0.43\end{array}$ & $* * *$ & $\begin{array}{c}0.24 \\
(-0.08 \\
0.56) \\
0.20\end{array}$ & $\begin{array}{c}0.14 \\
(-0.17,0.45) \\
0.12\end{array}$ & $\begin{array}{c}0.65 \\
(0.13 \\
1.16) \\
0.53\end{array}$ & & $\begin{array}{c}-0.11 \\
(-0.40 \\
0.17) \\
-0.09\end{array}$ & $\begin{array}{c}0.26 \\
(0.01 \\
0.52) \\
0.21\end{array}$ & $\begin{array}{c}0.52 \\
(0.22,0.82) \\
0.40\end{array}$ & $* *$ \\
\hline $\begin{array}{l}11 \\
12 \\
13 \\
14 \\
15\end{array}$ & Psychopathy & $\begin{array}{c}-0.04 \\
(-0.30 \\
0.23) \\
-0.02\end{array}$ & $\begin{array}{c}0.24 \\
(0.00,0.49) \\
0.15\end{array}$ & $\begin{array}{c}0.41 \\
(0.09 \\
0.73) \\
0.25\end{array}$ & * & $\begin{array}{c}-0.27 \\
(-0.65 \\
0.11) \\
-0.19\end{array}$ & $\begin{array}{c}0.17 \\
(-0.20,0.54) \\
0.12\end{array}$ & $\begin{array}{c}0.62 \\
(0.00,1.24) \\
0.43\end{array}$ & & $\begin{array}{c}0.13 \\
(-0.25 \\
0.52) \\
0.08\end{array}$ & $\begin{array}{c}0.31 \\
(-0.04 \\
0.66) \\
0.18\end{array}$ & $\begin{array}{c}0.39 \\
(-0.02,0.80) \\
0.22\end{array}$ & \\
\hline $\begin{array}{l}16 \\
17 \\
18 \\
19\end{array}$ & $\begin{array}{l}\text { Delinquency \& } \\
\text { contact with } \\
\text { police }\end{array}$ & $\begin{array}{l}-0.01 \\
(-0.15 \\
0.12) \\
-0.01\end{array}$ & $\begin{array}{c}0.20 \\
(0.08,0.32) \\
0.25\end{array}$ & $\begin{array}{c}0.42 \\
(0.26 \\
0.58) \\
0.51\end{array}$ & $* * *$ & $\begin{array}{c}-0.09 \\
(-0.26 \\
0.08) \\
-0.14\end{array}$ & $\begin{array}{c}0.05 \\
(-0.12,0.21) \\
0.08\end{array}$ & $\begin{array}{c}0.62 \\
(0.35,0.9) \\
0.96\end{array}$ & $* *$ & $\begin{array}{c}0.05 \\
(-0.16 \\
0.26) \\
0.05\end{array}$ & $\begin{array}{c}0.29 \\
(0.10 \\
0.48) \\
0.31\end{array}$ & $\begin{array}{c}0.40 \\
(0.18,0.62) \\
0.42\end{array}$ & $* * *$ \\
\hline $\begin{array}{l}20 \\
21 \\
22 \\
23\end{array}$ & Aggression & $\begin{array}{c}0.14 \\
(-0.02 \\
0.31) \\
0.15\end{array}$ & $\begin{array}{c}0.05 \\
(-0.10,0.20) \\
0.05\end{array}$ & $\begin{array}{c}0.46 \\
(0.26 \\
0.65) \\
0.46\end{array}$ & $* * *$ & $\begin{array}{c}0.12 \\
(-0.09 \\
0.34) \\
0.15\end{array}$ & $\begin{array}{c}0.09 \\
(-0.12,0.29) \\
0.11\end{array}$ & $\begin{array}{c}0.71 \\
(0.36 \\
1.06) \\
0.87\end{array}$ & $* *$ & $\begin{array}{c}0.14 \\
(-0.11 \\
0.38) \\
0.13\end{array}$ & $\begin{array}{c}0.04 \\
(-0.18 \\
0.25) \\
0.03\end{array}$ & $\begin{array}{c}0.40 \\
(0.14,0.66) \\
0.36\end{array}$ & $*$ \\
\hline $\begin{array}{l}24 \\
25 \\
26 \\
27 \\
28\end{array}$ & $\begin{array}{l}\text { Eating } \\
\text { disorders }\end{array}$ & $\begin{array}{c}0.21 \\
(-0.07 \\
0.49) \\
0.13\end{array}$ & $\begin{array}{c}0.09 \\
(-0.17,0.34) \\
0.05\end{array}$ & $\begin{array}{c}0.24 \\
(-0.09 \\
0.58) \\
0.14\end{array}$ & & $\begin{array}{c}0.12 \\
(-0.37 \\
0.61) \\
0.07\end{array}$ & $\begin{array}{c}-0.08 \\
(-0.56,0.40) \\
-0.04\end{array}$ & $\begin{array}{c}1.01 \\
(0.21 \\
1.81) \\
0.54\end{array}$ & & $\begin{array}{c}0.23 \\
(-0.07 \\
0.54) \\
0.17\end{array}$ & $\begin{array}{c}0.17 \\
(-0.10 \\
0.44) \\
0.12\end{array}$ & $\begin{array}{c}0.08 \\
(-0.24,0.40) \\
0.06\end{array}$ & \\
\hline $\begin{array}{l}29 \\
30 \\
31 \\
32\end{array}$ & Suicidality & $\begin{array}{c}1.23 \\
(0.70,2.14) \\
0.11\end{array}$ & $\begin{array}{c}1.59 \\
(0.98,2.60) \\
0.26\end{array}$ & $\begin{array}{c}2.14 \\
(1.16, \\
3.94) \\
0.42\end{array}$ & $* *$ & $\begin{array}{c}0.96 \\
(0.46,2.00) \\
-0.02\end{array}$ & $\begin{array}{l}0.87 \\
(0.42 \\
1.81) \\
-0.08\end{array}$ & $\begin{array}{c}2.50 \\
(0.98,6.39) \\
0.51\end{array}$ & & $\begin{array}{c}1.92 \\
(0.75,4.90) \\
0.36\end{array}$ & $\begin{array}{c}3.47 \\
(1.62 \\
7.43) \\
0.69\end{array}$ & $\begin{array}{c}2.49 \\
(1.00,6.19) \\
0.50\end{array}$ & $* *$ \\
\hline $\begin{array}{l}33 \\
34 \\
35 \\
36\end{array}$ & $\begin{array}{l}\text { Total functional } \\
\text { impairment }\end{array}$ & $\begin{array}{c}0.42 \\
(0.12 \\
0.71) \\
0.24\end{array}$ & $\begin{array}{c}0.29 \\
(0.02,0.56) \\
0.16\end{array}$ & $\begin{array}{c}0.89 \\
(0.54 \\
1.24) \\
0.50\end{array}$ & $* * *$ & $\begin{array}{c}0.75 \\
(0.25 \\
1.25) \\
0.39\end{array}$ & $\begin{array}{c}0.12 \\
(-0.37,0.62) \\
0.07\end{array}$ & $\begin{array}{c}1.39 \\
(0.58 \\
2.21) \\
0.73\end{array}$ & $* *$ & $\begin{array}{c}0.13 \\
(-0.20 \\
0.47) \\
0.09\end{array}$ & $\begin{array}{c}0.30 \\
(0.01 \\
0.60) \\
0.20\end{array}$ & $\begin{array}{c}0.73 \\
(0.38,1.08) \\
0.48\end{array}$ & $* * *$ \\
\hline $\begin{array}{l}37 \\
38 \\
39 \\
40\end{array}$ & $\begin{array}{l}\text { Functional } \\
\text { impairment } \\
\text { scale for } \\
\text { behavior }\end{array}$ & $\begin{array}{c}0.26 \\
(0.05 \\
0.47) \\
0.21\end{array}$ & $\begin{array}{c}0.18 \\
(-0.01,0.38) \\
0.14\end{array}$ & $\begin{array}{c}0.67 \\
(0.41 \\
0.92) \\
0.51\end{array}$ & $* * *$ & $\begin{array}{c}0.41 \\
(0.09 \\
0.72) \\
0.34\end{array}$ & $\begin{array}{c}0.18 \\
(-0.13,0.49) \\
0.15\end{array}$ & $\begin{array}{c}0.58 \\
(0.07 \\
1.09) \\
0.48\end{array}$ & $*$ & $\begin{array}{c}0.14 \\
(-0.15 \\
0.44) \\
0.11\end{array}$ & $\begin{array}{c}0.18 \\
(-0.08 \\
0.45) \\
0.14\end{array}$ & $\begin{array}{c}0.68 \\
(0.37,1.00) \\
0.51\end{array}$ & $* * *$ \\
\hline
\end{tabular}




\begin{tabular}{|c|c|c|c|c|c|c|c|c|c|c|c|c|}
\hline $\begin{array}{l}\text { Functional } \\
\text { impairment } \\
\text { scale for } \\
\text { anxiety }\end{array}$ & $\begin{array}{c}0.40 \\
(0.05 \\
0.75) \\
0.19\end{array}$ & $\begin{array}{c}0.44 \\
(0.12,0.76) \\
0.21\end{array}$ & $\begin{array}{c}0.94 \\
(0.52 \\
1.36) \\
0.44\end{array}$ & $* * *$ & $\begin{array}{c}0.70 \\
(0.11 \\
1.29) \\
0.31\end{array}$ & $\begin{array}{c}\text { JCPP } \\
0.43 \\
(-0.15,1.01) \\
0.19\end{array}$ & $\begin{array}{c}1.50 \\
(0.53 \\
2.47) \\
0.66\end{array}$ & $* *$ & $\begin{array}{c}0.12 \\
(-0.29 \\
0.52) \\
0.07\end{array}$ & $\begin{array}{c}0.37 \\
(0.02 \\
0.73) \\
0.21\end{array}$ & $\begin{array}{c}0.75 \\
(0.32,1.17) \\
0.41\end{array}$ & Pag \\
\hline $\begin{array}{l}\text { Functional } \\
\text { impairment } \\
\text { scale for } \\
\text { depression }\end{array}$ & $\begin{array}{c}0.46 \\
(0.12 \\
0.81) \\
0.22\end{array}$ & $\begin{array}{c}0.23 \\
(-0.09,0.55) \\
0.11\end{array}$ & $\begin{array}{c}0.89 \\
(0.47 \\
1.31) \\
0.42\end{array}$ & $* * *$ & $\begin{array}{c}0.83 \\
(0.25 \\
1.42) \\
0.37\end{array}$ & $\begin{array}{c}-0.02 \\
(-0.59,0.56) \\
-0.01\end{array}$ & $\begin{array}{c}1.69 \\
(0.73 \\
2.65) \\
0.75\end{array}$ & $* *$ & $\begin{array}{c}0.13 \\
(-0.27 \\
0.53) \\
0.07\end{array}$ & $\begin{array}{c}0.25 \\
(-0.10 \\
0.61) \\
0.14\end{array}$ & $\begin{array}{c}0.65 \\
(0.23,1.07) \\
0.36\end{array}$ & * \\
\hline $\begin{array}{l}\text { Functional } \\
\text { impairment } \\
\text { scale for eating } \\
\text { disorders }\end{array}$ & $\begin{array}{c}0.17 \\
(-0.05 \\
0.39) \\
0.13\end{array}$ & $\begin{array}{c}0.05 \\
(-0.15,0.26) \\
0.04\end{array}$ & $\begin{array}{c}0.25 \\
(-0.02 \\
0.51) \\
0.18\end{array}$ & & $\begin{array}{c}0.36 \\
(-0.06 \\
0.77) \\
0.22\end{array}$ & $\begin{array}{c}-0.13 \\
(-0.54,0.27) \\
-0.08\end{array}$ & $\begin{array}{c}0.50 \\
(-0.18 \\
1.18) \\
0.32\end{array}$ & & $\begin{array}{c}0.03 \\
(-0.16 \\
0.23) \\
0.04\end{array}$ & $\begin{array}{c}0.12 \\
(-0.06 \\
0.29) \\
0.13\end{array}$ & $\begin{array}{c}0.18 \\
(-0.03,0.38) \\
0.20\end{array}$ & \\
\hline
\end{tabular}

Note: Profiles "No ADHD and no irritability" and "Very low ADHD and very low irritability" were combined and used as the reference group with $\mathrm{n}=401$ (28.50\%) and $\mathrm{n}=539(38.31 \%)$, respectively. Ns vary between 1,372 and 1,407

Note 2: Adjusted for child's sex, family socioeconomic status, maternal age at child birth, no intact family, maternal and paternal hostile-reactive parenting score, maternal depression, maternal and paternal antisociality in adolescence.

${ }^{a}$ ADHD, Attention Deficit Hyperactivity Disorder

b Multiple testing corrected $p$-values using the Benjamini-Hochberg procedure $\left(*: p\right.$-value $<0.05,{ }^{* *}: p$-value $<0.01,{ }^{* * *}: p$-value $\left.<0.001\right)$

c Standardized effect size based on Cohen's d statistic (very small: <0.20; small: 0.20-0.50; medium: 0.50-0.80; large: 0.80-1.20; very large: 1.20-2.0; huge: > 2.0) or success rate difference

d Odds ratios were estimated using logistic regressions 